\title{
Judíos y arrianos: el mito de un acercamiento inexistente
}

\author{
Raúl GONZÁLEZ SALINERO * \\ Instituto de Filología - CSIC, Madrid
}

\section{UNA PRESUNCIÓN HISTÓRICA}

En su famosa obra apologética Complot contra la Iglesia, M. Pinay escribía, a propósito de la supuesta íntima relación existente entre judaísmo y arrianismo, las siguientes palabras: «El Arrianismo, la gran herejía que desgarró a la Cristiandad durante más de tres siglos y medio, fue la obra de un judío subterráneo, que en público practicaba el Cristianismo, ejemplo destacado e ilustre de los sucesores de Judas Iscariote, que son los clérigos, miembros de esa quinta columna judía introducida en el clero católico» ${ }^{1}$. Y, un poco más adelante, justificaba su teoría afirmando que «como principio básico de la doctrina de Arrio, figura su tesis judaica de la unidad absoluta de Dios, negando la Trinidad y considerando a Cristo Nuestro Señor solamente como la más excelsa de las criaturas, pero de ninguna manera

*rsalinero@filol.csic.es

El presente estudio ha sido posible gracias a un contrato de investigación del Programa I3P del CSIC, cofinanciado por el Fondo Social Europeo.

1 M. PINAy, Complot contra la Iglesia (Roma 1962; México 1969²) pág. 235 (a esta cuestión el autor dedica el capítulo titulado «El judío Arrio y su herejía», págs. 235-246)

Sefarad 64 (2004) págs. 27-74

(c) CSIC

ISSN 037-0894 
poseedor de una condición divina, siendo éste uno de los primeros intentos serios de judaización del Cristianismo» ${ }^{2}$.

Ciertamente, el arrianismo desarrolló una doctrina que, al margen de sus diferentes líneas de evolución, subordinaba el Hijo al Padre, negando de este modo la divinidad consustancial de Cristo ${ }^{3}$, lo que implicaba que fuese considerado frecuentemente como una herejía próxima al judaísmo. Para M. Simon, es posible que los judíos hubieran visto en el arrianismo la insinuación de una especie de regreso al monoteísmo estricto ${ }^{4}$. En cualquier caso, una gran parte de la historiografía ha asumido como una realidad incuestionable que los judíos y los arrianos llegaron a ser desde un principio «aliados naturales» contra el cristianismo ortodoxo ${ }^{5}$. Quienes defienden la

2 M. Pinay, Complot contra la Iglesia, pág. 236.

3 Sobre la doctrina cristológica y la disputa teológica arriana, vid. en general: J. N. D. KELly, Primitivos credos cristianos (London 1972; Salamanca 1980) págs. 277-313; M. WILES, Del evangelio al dogma. Evolución doctrinal de la Iglesia antigua (Madrid 1974) págs. 1-26; T. A. KOPECEK, A History of Neo-Arianism (Cambridge, Mass. 1979) págs. 61 ss.; J. N. D. KELLY, Early Christian Doctrines (London 1985) págs. 223 ss.; W. H. C. FREND, The Rise of Christianity (London 1986) págs. 492 ss. Entre los estudios monográficos, se han de destacar los siguientes: M. MEsLin, Les ariens d'Occident, 335-430 (Paris 1967); M. SimonetTI, La crisi ariana nel IV secolo (Roma 1975); R. C. GREgG y D. E. GROH, Early Arianism. A View of Salvation (London 1981) especialmente págs. 130; J. T. Lienhard, «Recent Studies in Arianism», Religious Studies Review 8 (1982) 331-337; R. C. GREGG (ed.), Arianism. Historical and Theological Reassessments (Philadelphia 1985) especialmente págs. 371-380 (con una amplia sección bibliográfica); R. WILliams, Arius: Heresy and Tradition (London 1987; reimpr. 2001); R. P. C. HANSON, The Search for the Christian Doctrine of God. The Arian Controversy, 318-381 (Edinburgh 1988); TH. BÖHM, Diф Christologie des Arius: dogmengeschichtliche Überlegungen unter besonderer Berïcksichtigung der Hellenisierungsfrage (St. Ottilien 1991); G. CH. STEAD, «Arius in Modern Research», Journal of Theological Studies 45 (1994) págs. 24-36; M. WILES, Archetypal Heresy. Arianism through the Centuries (Oxford 1996: reimpr. 2001).

${ }^{4}$ M. Simon, Verus Israel. A Study of the Relations between Christians and Jews in the Roman Empire (AD 135-425) (Paris 1948; reed. 1964; Oxford 1986) pág. 289.

L. LuCAS, The Conflict between Christianity and Judaism. A Contribution to the History of the Jews in the Fourth Century (Berlin 1910; Warminster 1993) págs. 21 y 94; J. PARKES, The Conflict of the Church and the Synagogue. A Study in the Origins of Antisemitism (London 1934) pág. 147; M. Simon, Verus Israel, 
tesis del filojudaísmo arriano aducen como prueba fehaciente del mismo la frecuente colaboración de ambos en los tumultuosos acontecimientos que, con motivo de las violentas luchas por el control del poder episcopal entre arrianos y «atanasianos», mantuvieron a la ciudad de Alejandría envuelta en un permanente conflicto político y religioso durante todo el siglo IV y parte del $\mathrm{V}^{6}$. En efecto, sabemos que, a raíz de la destitución de Atanasio de su sede episcopal el 18 de marzo del 339 y de la designación del arriano Gregorio de Capadocia como nuevo obispo de la ciudad, tanto paganos como judíos apoyaron activamente a la facción arriana en su enconado enfrentamiento con los partidarios nicenos ${ }^{7}$, y que, de nuevo, en época de Valente (364-378) se situaron al lado del obispo arriano Lucio en su lucha contra los seguidores de Pedro, el sucesor de Atanasio ${ }^{8}$.

pág. 286; D. JudanT, Judaïsme et christianisme. Dossier patristique (Paris 1969) pág. 69.

${ }^{6}$ Como ha puesto de relieve J. R. AJA SÁnCHEZ (Tumultus et urbanae seditiones: sus causas. Un estudio sobre los conflictos económicos, religiosos y sociales en las ciudades tardorromanas (s. IV) [Santander 1998] pág. 85), «fue en las asambleas de fieles y en torno a las elecciones episcopales donde solían manifestarse con toda su crudeza y gravedad las consecuencias de la escisión de nicenos y arrianos a principios del siglo IV, pues sólo de esta manera la querella doctrinal que les separó en dos bandos irreconciliables pudo trasladarse a un nivel popular».

7 Vid. Atanasio, Ep. encycl., 3-5 (PL 25, cols. 228 ss.); cfr. Apol. contr. Ar., 83 (PL 25, col. 396). El 24 de octubre del 357, Jorge de Capadocia fue nombrado obispo arriano de Alejandría entre los aplausos nuevamente de paganos y judíos. Una vez más, Atanasio sería expulsado de la ciudad el 2 de octubre del año siguiente (vid. G. BARDY, Saint Athanase [Paris $1925^{3}$ ] pág. 134).

8 Teodoreto de Ciro, Hist. eccl., IV, 18-19. (PG 82, cols. 1163-1176); Lucifer de Cagliari, Athan., II, 22 (ed. G. F. DiERCKS, en $C C L, 8$, 1978, pág. 114); Casiodoro, Hist. Trip., VII, 37, 40 (PL 69, cols. 1097 y 1101). Sobre esta serie de acontecimientos, vid. H. M. Gwatkin, Studies of Arianism. Chiefly Referring to the Character and Chronology of the Reaction Which Followed the Council of Nicaea (Cambridge, 1882; reed. 1900; reimpr. New York 1978) págs. 57-59; L. LuCAS, The Conflict, pág. 4; J. PARKEs, The Conflict, pág. 186; H. I. BELL, «AntiSemitism in Alexandria», Journal of Roman Studies 31 (1941) págs. 16-17; D. JUDANT, Judaïsme et christianisme, págs. 69-70; E. H. FLANNERY, Veintitrés siglos de antisemitismo. Desde el mundo antiguo hasta la lucha por la emancipación (New York 1964; Buenos Aires 1974) págs. 120-121; M. SimonetTi, La crisi ariana, pág. 143; M. Simon, Verus Israel, pág. 224; A. M. RABEllo, Giustiniano, 
Algunos investigadores han tratado de descubrir las razones por las que los judíos tomaron parte activa a favor de los arrianos en los continuos conflictos que enfrentaban a ambos grupos cristianos en Alejandría. La clave estaría, por tanto, en las profundas conexiones que aparentemente unían en una causa común tanto a judíos como a arrianos. Según A. M. Rabello, dicha relación íntima tenía como punto de partida a la secta de los melecianos que, al oponerse al patriarca católico de Alejandría, se había aproximado por razones tácticas a los arrianos, sucumbiendo finalmente a su influencia. Al parecer, Teodoreto de Ciro sostuvo que los monjes melecianos habían adoptado desde el principio prácticas religiosas propias de los judíos y samaritanos ${ }^{9}$. A pesar de que (como veremos más adelante) la acusación de judaísmo era muy frecuente en la dialéctica nicena contra el arrianismo, la vinculación con el movimiento meleciano podría resultar en este caso, según A. M. Rabello, muy significativa, ya sea porque en el siglo I existía en Egipto una secta ascética que pudo haber influido en el monaquismo meleciano, ya sea por la posible influencia ejercida por la tradición judeo-samaritana en la primitiva iglesia de Alejandría ${ }^{10}$. En cualquier caso, M. Simon consideraba que, aunque el factor religioso no fue decisivo, las «simpatías doctrinales» pudieron haber hecho que la «confabulación» de judíos y arrianos resultara mucho más fácil ${ }^{11}$. Sin embargo, las fuentes no aportan ninguna prueba de tales supuestas «simpatías», y tampoco parece que la intervención de los paganos al lado de quienes se oponían a los atanasianos respondiera a la sorprendente aparición de una sintonía religiosa. Nada indica, por tanto, que en el caso de Alejandría, la momentánea alianza entre judíos y arrianos fuese motivada por un supuesto e infundado acercamiento doctrinal, sino más bien por poderosas razones derivadas de la existencia de un conflicto polí-

Ebrei e Samaritani alla luce delle fonti storico-letterarie, ecclesiastiche e giuridiche (Milano 1987-1988) I, pág. 89.

${ }^{9}$ Teodoreto de Ciro, Hist. Eccl., I, 8 (PG 82, col. 932B).

${ }^{10}$ A. M. Rabello, Gilustiniano, Ebrei e Samaritani, I, págs. 88-89.

"M. Simon, Verus Israel, pág. 474, n. 103. 
tico (en el que intervino directamente el poder imperial) entre fuerzas antagónicas que trataban de imponer su hegemonía y en el que la cuestión religiosa desempeñó sólo un papel incidental ${ }^{12}$.

Si el arrianismo hubiese llevado implícita una actitud filojudaica, habría que esperar que Constancio, un emperador arriano que estaba firmemente decidido a convertir esta «herejía» en la religión oficial del Estado, desarrollara una política favorable al judaísmo o, al menos, que no resultara perjudicial para las comunidades judías del Imperio. Sin embargo, lejos de adoptar dicha actitud, podemos descubrir en Constancio una legislación claramente antijudía ${ }^{13}$. En el año 353 dirige desde Milán una constitución al Prefecto del Pretorio de Oriente, Talasio, en la que confirmaba todo lo que ya había dispuesto en una ley precedente (que no ha llegado hasta nosotros) en torno a la prohibición que pesaba sobre el cristiano de convertirse a la religión judía y de asistir a sus sacrílegas reuniones, bajo pena de confiscación de sus bienes en favor del Fisco ${ }^{14} \mathrm{y}$, dos años después, decide prohibir una práctica muy extendida entre los judíos de la Diáspora: el levirato ${ }^{15}$. Ante tales evidencias, incluso M. Pinay,

\footnotetext{
${ }^{12}$ Vid. J. PARKeS, The Conflict, pág. 147. A juzgar también por los acontecimientos ocurridos posteriormente en la Alejandría de época del obispo Cirilo, se ha de concluir que los judíos siempre estuvieron dispuestos a apoyar a cualquier grupo o movimiento social o religioso que se encontrase en oposición a la Iglesia oficial: vid. R. L. WILKEN, Judaism and the Early Christian Mind. A Study of Cyril of Alexandria's Exegesis and Theology (New Haven - London 1971) págs. 46-47 y 54-68. Sobre la actitud de Cirilo de Alejandría frente a los judíos en el marco de un contexto marcado por el conflicto en torno al «poder religioso», vid. R. TEJA, La "tragedia» de Éfeso (431): Herejía y poder en la Antigüedad tardía (Santander 1995) págs. 28-29.

${ }^{13}$ R. GONZÁlez SALINERO, El antijudaísmo cristiano occidental (siglos IV y V) (Madrid 2000) pág. 77.

${ }^{14}$ Cod. Theod., XVI, 8, 7 (ed. TH. Mommsen, Codex Theodosianus libri XVI cum Constitutionibus Sirmondianis [Dublin - Zürich $1971^{4}$ ] pág. 888). Vid. A. LINDER, The Jews in Roman Imperial Legislation (Detroit - Jerusalem 1987) págs. 151-154; R. GONZÁlez SAlinero, El antijudaísmo cristiano, pág. 86.

${ }^{15}$ Cod. Theod., III, 12, 2 (ed. Th. Mommsen, Codex Theodosianus, págs. 150151). Vid. G. DE BonflLs, «Legislazione ed Ebrei nel IV secolo. Il divieto dei matrimoni misti», Bolettino dell'Istituto di Diritto Romano "Vittorio Scialoja» 90 (1987) págs. 422-423; R. GONZÁlEZ SALINERO, El antijudaísmo cristiano, págs. 129-
} 
acérrimo defensor del «malicioso» filojudaísmo arriano, debe admitir que la actitud de Constancio no responde a este impulso y lo justifica de la siguiente manera: «Es increíble cómo puede a veces el Judaísmo convertir en aliados inconscientes a los que han sido sus jurados enemigos, empleando para lograrlo, como en este caso, las más innobles conjuras. Pero casos como el de Constancio se han dado algunos en la historia» ${ }^{16}$. Es muy posible que, en esta ocasión, la asunción del mito fuese mucho más inmediata ante la percepción de que el poder temporal había dejado de estar al servicio exclusivo de la ortodoxia para convertirse en el más fiel colaborador de la «herejía». Los partidarios del credo de Nicea comenzaron a desarrollar una campaña de descrédito contra sus poderosos adversarios y, para ello, no vacilaron en asimilar a los arrianos con los judíos, reconocidos enemigos de Cristo y del cristianismo ${ }^{17}$.

Desde el punto de vista de la teología política, la controversia arriana suscitó un largo debate sobre el concepto de la monarquía divina y su relación con el monoteísmo. En este sentido, no es casual que precisamente en esta época los Padres de la Iglesia tomaran conciencia del origen judío del monoteísmo y que cobrase mayor fuerza la defensa de la antigua línea apostólica de la Trinidad frente a dicho monoteísmo, germen de toda disensión política y religiosa ${ }^{18}$.

130. Sobre la institución del levirato, vid. M. GoLDSTEIn, Derecho hebreo a través de la Biblia y el Talmud (Buenos Aires 1947) págs. 243-246; B. COHEN, Jewish and Roman Law. A Comparative Study (New York 1966) I, págs. 321 ss.

${ }^{16}$ M. PinAy, Complot contra la Iglesia, pág. 244 (cfr. pág. 246).

${ }^{17}$ Vid. F. Blanchetiere, «Privilegia odiosa au non? L'évolution de l'attitude officielle à l'endroit des Juifs et du judaïsme (312-395)», en F. BLANChETIÈrE, Aux sources de l'anti-judaïsme chrétien, (Jerusalem 1995) pág. 122.

${ }^{18}$ E. PETERSON, El monoteísmo como problema político (München 1951; Madrid 1999) pág. 93. Como ha puesto de relieve B. de Margerie, a ojos de la ortodoxia, Arrio trató de destruir el dogma trinitario a partir de un sistema de creencias inspirado en la filosofía griega (sobre todo, en el platonismo); en el judaísmo en tanto que negaba la divinidad de Jesús, y en el paganismo en cuanto a la afirmación de la existencia de unas «divinidades secundarias o intermedias» (Jesús y el Espíritu Santo) entre el Dios supremo y el mundo (vid. B. DE MARGUERIE, La Trinité chrétienne dans l'histoire [Paris 1975] pág. 130). 
Como muy bien ha estudiado E. Peterson, la insistencia arriana en el concepto de la monarquía divina puso en entredicho la doctrina nicena. El arriano Eunomio consideraba que la perfecta simbiosis entre la supremacía de Dios y la monarquía política debía servir como principio incuestionable del poder imperial. En las Constituciones Apostólicas, el arriano que refundió esta obra utiliza la profecía de Daniel $(2,34)$ para demostrar que Cristo, el Hijo del Hombre, se había convertido en una gran montaña que llenaba toda la tierra y que destruía la poliarquía política de los poderes locales y el politeísmo de los impíos, predicando de esta forma al Dios único e instaurando la absoluta soberanía de los romanos ${ }^{19}$. El monoteísmo se convirtió en una exigencia política, en un componente imprescindible del Imperio, en un argumento valiosísimo para la legitimación divina de la autoridad secular ${ }^{20}$, pero al mismo tiempo favorecía extraordinariamente la controversia teológica creando una tensión continua en torno a la definición de la ortodoxia y la herejía ${ }^{21}$. Según E. Peterson, «en el instante en que el concepto de la monarquía divina, que no era más que el reflejo de la monarquía terrestre del Imperio romano, entraba en colisión con el dogma de la Trinidad, la controversia sobre este dogma se convertía en una lucha eminentemente política» ${ }^{22}$. No es de extrañar, por tanto, que en un principio el emperador, llevado por un apremiante interés político, se inclinase del lado de los arrianos, ya que «la doctrina ortodoxa de la Trinidad amenazaba en verdad la teología política del Imperio romano» ${ }^{23}$. Por ello, el denodado intento de vinculación de la doctrina arriana con el judaísmo pretendía deslegitimar cualquier justi-

\footnotetext{
${ }^{19}$ Const. Apost., V, 20, 11 (ed. M. Metzger, Les Constitutions Apostoliques [Paris 1985-1987] II, pág. 280; ed. F. X. FUnK, Didascalia et Constitutiones Apostolorum [Paderborn 1905] pág. 297).

${ }^{20}$ G. FOWDEN, Empire to Commonwealth. Consequences of Monotheism in Late Antiquity (Princeton 1993) págs. 87-88.

${ }^{21}$ G. Fowden, Empire to Commonwealth, pág. 108.

${ }^{22}$ E. Peterson, El monoteísmo, pág. 92.

${ }^{23}$ E. Peterson, El monoteísmo, pág. 93.
} 
ficación divina del poder al margen de la teología trinitaria, convertida en la expresión más desarrollada y sublime del monoteísmo. La reducción del credo arriano al monoteísmo estricto del judaísmo desautorizaba de forma directa cualquier pretensión política basada en su doctrina, ocultando intencionadamente la diferencia que separaba el monoteísmo étnico propio del judaísmo del monoteísmo universal y proselitista que caracterizaba al cristianismo ${ }^{24}$ y al que, como evidencian las fuentes, se encontraba adherido el arrianismo ${ }^{25}$.

Al igual que ocurría con la historiografía pagana respecto a la opinión que merecían los emperadores dependiendo de su desprecio o afinidad hacia los ideales e intereses senatoriales, la historiografía católica se mostraba proclive a emitir su veredicto sobre el reinado de los emperadores cristianos en virtud de su actitud hacia la ortodoxia y la herejía. Es evidente que tanto Constancio II como Valente, emperadores arrianos, fueron especialmente denigrados por los autores de profesión nicena. En este sentido, no resulta extraño que sus respectivos reinados fueran considerados como una época de calamidad y persecución para la ortodoxia y, en cambio, como un momento dulce para la herejía y el judaísmo. La peculiar historia de José de Tiberíades, transmitida por Epifanio de Salamina ${ }^{26}$, constituye un fiel reflejo de esta percepción católica. Según la narración, José fue un eminente judío que decidió convertirse al cristianismo

\footnotetext{
${ }^{24}$ G. FowdEn, Empire to Commonwealth, pág. 71.

${ }^{25}$ Según A. Laato, la influencia de la filosofía platónica llevó a los arrianos a la conclusión de que el Hijo era sólo una «creatura» del Padre, lo que les convertía en defensores de un monoteísmo que, aunque no totalmente idéntico, era tan ardiente como el de los judíos. Sobre el particular, vid. A. LAATo, Monotheism, the Trinity and Mysticism. A Semiotic Approach to Jewish-Christian Encounter (Frankfurt am Main 1999) págs. 136-137.

${ }^{26}$ Epifanio de Salamina, Panar., 30, 4, 1 - 30, 12-9 (GCS 25, págs. 338-348). Sobre este tema, vid. M. AvI-YONAH, The Jews under Roman and Byzantine Rule. A Political History of Palestine from the Bar Kokhba War to the Arab Conquest (Jerusalem 1984) págs. 167-168; T. C. G. THORNTON, «The Stories of Joseph of Tiberias», Vigiliae Christianae 44 (1990) págs. 54-63; G. STEMBERGER, Jews and Christians in the Holy Land. Palestine in the Fourth Century (München 1987; Edinburgh 2000) págs. 72-74.
} 
en los últimos años del reinado de Constantino. Su amistad con el emperador le procuró el título de comes, lo que le permitió gozar de la autoridad suficiente para impulsar la construcción de numerosas iglesias por toda Palestina. A pesar de haberse ganado la animadversión de judíos y arrianos, a los que también combatió con energía en numerosas ocasiones, su rango le salvó de las persecuciones arrianas durante el reinado de Constancio II. Realmente, resultó milagroso que no pereciera entonces si, como afirma Epifanio, era el único ortodoxo de Escitópolis, ciudad completamente arriana en esta época. El trasfondo de este curioso episodio nos permite constatar que, desde la óptica católica, judíos y arrianos compartían una misma doctrina y que, en virtud de ella, no era infrecuente su convivencia en un mismo entorno geográfico ni la estrecha colaboración en su común oposición a la ortodoxia.

Igualmente, la tradición católica hizo de Valente un emperador filojudío. La asociación de judíos y arrianos en la lucha por instalar a Lucio en la silla episcopal de Alejandría y la protección que este emperador (según Teodoreto de Ciro y otras fuentes posteriores) prodigó a sinagogas y templos paganos en Antioquía, constituirían una prueba irrefutable de su proclividad a favorecer a los judíos, aliados naturales de los arrianos en detrimento de la «verdadera Iglesia» ${ }^{27}$. Es muy posible que, como ha afirmado M. Avi-Yonah, la feroz oposición católica suscitara en Valente cierta benevolencia respecto a judíos y paganos con el fin de impedir que aumentase el número de sus enemigos ${ }^{28}$. Nada autorizaría, sin embargo, a pensar que mantuviera una actitud filojudaica. De hecho, en su legislación

${ }^{27}$ Vid. Teodoreto de Ciro, Hist. Eccl., IV, 24, 2 (GCS 19, pág. 262); Chronicon Iacobi Edesseni, ed. BROoKs, Chronica, CSCO, III/II, pág. 224; Paulo Diácono, Hist. miscell., XII (PL 95, col. 928); Teofanes, Chron. (ed. C. DE BoOR, Theophanis Chronographia [Leipzig 1883], I, págs. 58-59); Cedreno, Hist. comp., 544 (PG 121, col. 593); Miguel el Sirio, ed. Снавот [Paris 1901] I, pág. 294). Sobre el particular, vid. L. LuCAS, The Conflict, págs. 21 y 63; A. M. RABEllo, Giustiniano, Ebrei e Samaritani, I, pág. 36.

${ }^{28}$ M. Avi-YonaH, The Jews under Roman and Byzantine Rule, pág. 209. 
no se detecta ninguna medida en favor de los judíos. Antes bien, habría que considerar a su hermano Valentiniano I, de credo católico, mucho más filojudío, ya que, según la lógica de la argumentación que siguen aquellos que defienden una alianza entre judíos y arrianos, fue él quien, de hecho, emitió al menos una ley que favorecía a los judíos. En ella prohibía que las tropas del ejército ocupasen como alojamiento las sinagogas ejerciendo el derecho de hospitalidad (metatum ${ }^{29}$. En realidad, con esta ley el emperador trataba de hacer respetar la legislación que protegía a los lugares sagrados y, puesto que el judaísmo aún contaba (aunque sólo fuese formalmente) con el reconocimiento de licita religio, las sinagogas debían ser consideradas como aedes sacra ${ }^{30}$.

Tampoco existe ninguna evidencia de que los vándalos arrianos desarrollasen una política filojudía en el norte de África. Es cierto que, durante la época inmediatamente anterior a la invasión, las autoridades eclesiásticas sostuvieron una actitud antijudía que encontró su reflejo en una agresiva legislación contra los judíos, y que la llegada de los bárbaros frenó una situación adversa que comenzaba a ser insostenible. Aunque parece que los judíos lograron desenvolverse con cierta libertad durante la época bárbara, no hay motivos para pensar que los vándalos fueran más allá de la mera tolerancia religiosa. La larga pausa que experimentó la opresión católica sobre los judíos durante el período vándalo no constituye un argumento objetivo para presuponer la existencia de una declarada actitud positiva hacia ellos. De hecho, como ya he señalado en otro lugar, no habría que olvidar que «Genserico supo capitalizar políticamente las ideas religiosas cristianas y no cristianas, convirtiendo la disputa contra Roma en una lucha del arrianismo contra el catolicismo perseguidor. Esto le valió el apoyo de los arrianos africanos y de mani-

${ }^{29}$ Cod. Theod., VII, 8, 2 (ed. TH. Mommsen, Codex Theodosianus, pág. 327). Vid. A. Linder, The Jews, págs. 161-163; F. PERGAMI, La legislazione di Valentiniano e Valente (364-375) (Milano 1993) pág. 211.

${ }^{30} \mathrm{Vid}$. R. GONZÁlez SALINERO, «Una constitución de Valentiniano I sobre el respeto a los lugares de culto judíos», Polis 10 (1998) págs. 157-166. 
queos y donatistas, así como de otros grupos que se mostraban reacios a la dominación católica, entre los que se encontraban los judíos» ${ }^{31}$.

Ahora bien, la política seguida por el arriano Teodorico respecto a la minoría judía en la Italia ostrogoda, ha constituido sin duda alguna la prueba de mayor peso dentro de la argumentación en la que se apoya la tesis del pretendido filojudaísmo arriano ${ }^{32}$. En efecto, durante su reinado, Teodorico, un monarca con un elevado sentido de la justicia y del respeto a la tradición jurídica romana ${ }^{33}$, actuó enérgicamente contra los cristianos que tanto en Roma (entre el 509 y el 511) como, años más tarde, en Rávena (hacia el 519 ó 520 ), habían destruido e incendiado diversas sinagogas ${ }^{34}$. Tampoco dejó desamparados a los judíos de Génova y Milán que habían solicitado su protección contra el malintencionado intrusismo de los clérigos cristianos en sus respectivas comunidades. En todos estos casos podemos constatar que Teodorico siguió escrupulosamente las leyes romanas que garantizaban la libertad de culto y protegían los lugares de reunión judíos. Sin embargo, por esta misma razón no permitió ni la construcción de nuevas sinagogas ni el embellecimiento de las antiguas. En este sentido, al conceder la petición que le hicieron los judíos de Génova para reparar su sinagoga, Teodori-

${ }^{31}$ R. González SALINero, Poder y conflicto religioso en el norte de África: Quodvultdeus de Cartago y los vándalos (Madrid 2002) pág. 69 (a esta cuestión dedico las págs. 68-70). Vid. además R. GonZÁlEZ SALINERO, «The Anti-Judaism of Quodvultdeus in the Vandal and Catholic Context of the $5^{\text {th }}$ Century in North Africa», Revue des Études Juives 155 (1996) págs. 456-458. Según J. Parkes, resulta además muy sospechoso que las fuentes católicas del momento y de épocas posteriores no mencionen a los judíos tomando parte en las persecuciones arrianas contra los católicos (J. PARKES, The Conflict, pág. 147).

32 Vid. B. BlumenKranZ, Juifs et Chrétiens dans le monde occidental, 430-1096 (Paris - La Haye 1960) págs. 35 y 181-182.

${ }^{33}$ Vid. J. MoorheAD, Theodoric in Italy (Oxford 1992) pág. 79; B. SAITTA, La civilitas di Teodorico. Rigore amministrativo, "toleranza" religiosa e recupero dell'antico nell'Italia ostrogoda (Roma 1993) pág. 10.

${ }^{34}$ Casiodoro, Var., 4, 43 (ed. A. J. FridH en CCL 96, pág. 171); Anon. Vales., 14, 81-82 (ed. J. C. Rolfe, Ammianus Marcellinus [Cambridge - London 1963] III, págs. 558-560). 
co les advirtió al mismo tiempo de que, según los decretos imperiales anteriores ${ }^{35}$, sólo les estaba permitido poner un tejado sobre los antiguos muros del edificio, sin que ello implicase el embellecimiento ni el engrandecimiento de la construcción ${ }^{36}$. Así pues, la «tolerancia» que Teodorico demuestra tener hacia la minoría judía vendría determinada fundamentalmente por el respeto a las normas que había heredado del Derecho romano ${ }^{37}$. Se podría afirmar que, en realidad, su posición política no llevó consigo la idea de filojudaísmo, sino más bien de juridicidad ${ }^{38}$. La imposibilidad de fundamentar dicha política en un hipotético acercamiento doctrinal entre el arrianismo y el judaísmo se vería además confirmada por su tajante oposición teológica e ideológica a la religión judía ${ }^{39}$. Así, por ejemplo, en la carta que dirigió a los judíos milaneses podemos leer el siguiente reproche: «pero, ¿por qué, oh judío, pides la paz terrenal si eres incapaz de encontrar la tranquilidad eterna?» ${ }^{40}$, y a los judíos de Génova, a los que había permitido la reparación de su sinagoga, declara la sincera opinión que le merece el credo judaico: «Os concedemos sin duda el permiso, pero honestamente censuramos el voto de los que viven en el error» ${ }^{41}$.

\footnotetext{
${ }^{35}$ Cfr. Nov. Theod., 3, 3, 5 (ed. P. M. MEYER, Leges Novellae ad Theodosianum pertinentes [Berlin 1905; reimpr. 1962] págs. 8-9).

${ }^{36}$ Casiodoro, Var., 2, 27 (CCL 96, pág. 76).

${ }^{37}$ F. Lovsky, Antisémitisme et mystère d'Israel (Paris 1955) págs. 106-107. Como ya se preguntó retóricamente este autor, si Teodorico se limitó simplemente a reestablecer el status quo ante, «en quoi cette attitude diffère-t-elle de la politique de certains princes "trinitaires"?» (p. 110). Cfr. R. GonZÁlez SAlinero, El antijudaísmo cristiano, págs. 76-77.

${ }^{38}$ Sobre el particular, vid. R. GonZÁlez SALINERo, «Teodorico el Grande, Casiodoro y los judíos: tolerancia jurídica y polémica antijudía», Cassiodorus 4 (1998) págs. 350-352.

${ }^{39}$ Vid. F. LOVSKY, Antisémitisme et mystère, pág. 110; R. GONZÁLEZ SAlinero, «Teodorico el Grande», pág. 252.

${ }^{40}$ Casiodoro, Var., 5, 37 (CCL 96, pág. 211): sed quid, Iudaee, supplicans temporalem quietem quaeris, si aeternam requiam inuenire non possis?

${ }^{41}$ Casiodoro, Var., 2, 37 (CCL 96, pág. 83): Damus quidem permissum, sed errantium uotum laudabiliter improbamus.
} 
Posiblemente una de las mayores virtudes de Teodorico fuera su capacidad para evitar que sus convicciones personales en contra de la religión judía interfiriesen en sus responsabilidades de gobierno y en su sentido de la justicia, lo que, de forma indirecta, favoreció considerablemente las condiciones de vida de los judíos de su reino ${ }^{42}$. Ésta sería la razón primordial, si no la única, por la que decidieron luchar al lado de los godos en la defensa de la ciudad de Nápoles ante el ataque de las tropas bizantinas de Belisario en el año $536^{43}$. Pero, como muy bien ha afirmado F. Lovsky, si los judíos se decantaron por el lado ostrogodo no fue tanto porque tuviesen que elegir entre arrianismo y ortodoxia sino más bien entre la implacable intolerancia bizantina y la relativa, pero innegable, tolerancia jurídica goda ${ }^{44}$. Por motivos parecidos, en el año 508 los judíos de Arlés no dudaron en defender la ciudad, que se hallaba en manos de los godos de profesión arriana, frente a las tropas católicas del rey franco Clodoveo ${ }^{45}$.

A su vez, el mito del filojudaísmo arriano se nutrió igualmente del silencio de las fuentes visigodas durante el siglo VI. La ausencia de un adecuado examen crítico del significado del proceso de reducción que llevó a cabo Alarico II de la legislación procedente del

\footnotetext{
${ }^{42}$ Según S. W. Baron, es posible que la actitud anticatólica de Teodorico le hiciese sentir mayor aprecio por la minoría judía. Vid. S. W. BARON, Historia social y religiosa del pueblo judío, III. Herederos de Roma y Persia (New York 1954; Buenos Aires 1968) pág. 241, n. 30.

${ }^{43}$ Procopio de Cesarea, Bell., V, 8, 41-42 (ed. H. B. DewIng, Procopius, History of the Wars [London - New York 1919] III, pág. 80); V, 10, 24-26 (H. B. DEwING, Procopius, pág. 98). Vid. A. M. RABELlo, Giustiniano, Ebrei a Samaritani, I, pág. 203. Autores como B. LuISELLI («Teodorico e gli ostrogoti tra romanizzazione e nazionalismo gotico», Romanobarbarica 13 (1994-1995) pág. 96) todavía piensan que la «fe común» en la naturaleza no divina de Cristo pudo haber sido el punto de unión de la alianza judeo-goda.

${ }^{44} \mathrm{~F}$. Lovsky, Antisémitisme et mystère, pág. 110.

${ }^{45}$ Vid. Cipriano de Toulón, Vit. Caes., I, 21-23 (PL 67, cols. 1011-1012= MGH, Scrip. Mer. III, págs. 467-468). Sobre este episodio, vid. P. MIKAT, Caesarius von Arles und die Juden (Opladen 1996) págs. 20 ss.; R. GonZÁlez SAlinero, El antijudaísmo cristiano, págs. 248-249.
} 
Codex Theodosianus que afectaba a los judíos, propició que se asumiese como indiscutible la teoría de que éstos gozaron de una abierta libertad religiosa bajo los monarcas visigodos de credo arriano y que sólo sufrirían persecución y adversidad a partir de la conversión al catolicismo de Recaredo en el año $589^{46}$. Sin embargo, la omisión de algunas disposiciones antijudías en la compilación del Breviario obedeció fundamentalmente a un proceso de reajuste de la legislación anterior a partir del cual se desestimaron algunas leyes por su inoperancia en una época en la que ya habían desaparecido las situaciones o circunstancias que en su momento las motivaron o por la existencia de ciertas contradicciones e incongruencias. Por otro lado, dicha reducción no implicó en absoluto una disminución del rigor o dureza de las leyes cuya vigencia fue renovada. Es cierto que carecemos de información sobre la aplicabilidad real de todas las disposiciones que formaron el nuevo código jurídico visigodo, pero no puede negarse que, al menos formalmente, tuvieron plena vigencia hasta el 654, fecha en que Recesvinto decidió abolir el Breviario alariciano. Cualquier suposición sobre la relajación en la aplicación de las normas contra los judíos no pasaría de ser una mera hipótesis. Lo cierto es que el talante intransigente de la legislación antijudía recuperada del Código Teodosiano autoriza a suponer que el espíritu y la intención del compilador visigodo no era, ni muchísimo menos, favorable a los judíos ${ }^{47}$. Es muy posible que el posterior endurecimiento de la política antijudía de época católica haya podido contribuir, por contraste, a la aparición de una visión mucho más indulgente del trato a los judíos en época arriana. Sin embargo, la herencia recogida del antijudaísmo del Imperio cristiano no permite pensar que los monarcas anteriores a Recaredo fueran, en virtud de una aparente simpatía de carácter doctrinal, tolerantes con la minoría judía. La diferencia entre ambas épocas estribaría fundamentalmente en el desarrollo de un mayor grado de

\footnotetext{
${ }^{46}$ Vid. por ejemplo, J. PARKes, The Conflict, pág. 322; A. M. RABELlo, Giustiniano, Ebrei e Samaritani, I, págs. 67-68 y II, pág. 602;

${ }^{47}$ Vid. F. Lovsky, Antisémitisme et mystère, pág. 109.
} 
represión dentro de una misma línea ideológica de sentido claramente antijudío ${ }^{48}$.

\section{MITO Y POLÉMICA ANTIARRIANA}

El mito del filojudaísmo arriano se originó como imagen degradante de la desviación doctrinal de Arrio y sus seguidores y, apenas surgida la controversia sobre la definición de la ortodoxia, se extendió profusamente en la literatura cristiana antiherética. No puede decirse que la intervención del «error judaico» en una herejía fuese una novedad, pues llegó a estar presente en casi todas las «aberraciones» heterodoxas que sacudieron a la Iglesia en esta época, pero con el arrianismo adquirió ciertamente carta de naturaleza. Hubo, sin duda, algunos movimientos judaizantes que, como reminiscencias de los primeros siglos del cristianismo, todavía creían compatibles los preceptos de la Ley con la defensa a ultranza de la mesianidad de Jesús (los nazarenos, por ejemplo). Sin embargo, la progresiva desvinculación del judaísmo estuvo acompañada de la necesidad de establecer una única doctrina dentro del cristianismo. Se podría afirmar con M. Simon que la renuncia definitiva a los principios normativos de la religión mosaica dio lugar a una amplia literatura antijudía que, a su vez, supuso el reflejo fiel del desarrollo de la propia teología cristiana desde sus mismos inicios hasta la más completa definición del «trinitarismo» de Nicea ${ }^{49}$. No es, por ello, extraño que a lo largo de este proceso cualquier desviación del camino trazado por la ortodoxia se atribuyera, de forma directa o indirecta, a una especie de deseo de emulación (más o menos enmascarada) de los judíos. Incluso se llegó a pensar que éstos animaban en secreto a la herejía. De ahí que la subordinación de la naturaleza del

\footnotetext{
${ }^{48}$ Sobre el particular, vid. R. GonZÁlEZ SALINERo, «Los judíos en el reino visigodo de época arriana: consideraciones sobre un largo debate», en Judaísmo Hispano. Estudios en memoria de José Lacave Riaño, ed. E. ROMERo (Madrid 2002) II, págs. 399-408.

${ }^{49}$ M. Simon, Verus Israel, pág. 160.
} 
Hijo a la del Padre y la restricción o incluso negación de la divinidad de Cristo, suscitaran frecuentemente la acusación de que los arrianos propugnaban en realidad una distorsión judaizante de la verdadera doctrina. Para la ortodoxia, no existían dudas de que Arrio se había dejado simplemente seducir por el judaísmo ${ }^{50}$. De hecho, como muy bien ha observado J.-M. Poinsotte, el léxico antijudío (perfidi, uenenum, caeca impietas, liuor inuidiae) pasó a formar parte de la diatriba antiarriana y viceversa ${ }^{51}$.

Atanasio fue el primer padre de la Iglesia que propagó el mito de esta pretendida cercanía doctrinal entre judaísmo y arrianismo ${ }^{52}$. En este sentido, habría que preguntarse si las desagradables circunstancias que, en repetidas ocasiones, le obligaron a abandonar la silla episcopal de Alejandría, y en las que los judíos intervinieron activamente en su contra, no suscitaron una explicación ideológica que trascendiese cualquier motivación meramente política. Sea como fuere, lo cierto es que la alianza entre judíos y arrianos en Alejandría propició que se propagase por medio de su pluma la existencia de una supuesta afinidad religiosa entre ambos, lo que les convertía en enemigos aún más peligrosos ${ }^{53}$. Para Atanasio, no había duda de

${ }^{50}$ Vid. A. HARNACK, Lehrbuch der Dogmengeschichte (Tübingen 1909) II, pág. 209; J. JUSTER, Les Juifs dans l'Empire romain. Leur condition juridique, économique et sociale (Paris 1914) I, pág. 284, n. 1; H. SCHRECKENBERG, Die christlichen Adversus-Judaeos-Texte und ihr literarisches und historisches Umfeld (1-11 Jh.) (Frankfurt am Main 1982; 3a ed. 1995) pág. 257.

${ }^{51}$ Vid. J.-M. POINSOTTE, «Chrétiens et Juifs au IV siécle: "Eux, c'est eux, nous, c'est nous"», en Les chrétiens face à leurs adversaires dans l'Occident latin au IV siécle, ed. J.-M. PoINSOTTE (Rouen 2001) pág. 35.

${ }^{52}$ Vid. Atanasio, Or. Adv. Ar., I, 8 (PG 26, cols. 25-28); I, 10 (cols. 32-33); I, 38 (cols. 88-89); I, 39 (cols. 92-93); I, 55 (cols. 125-128); II, 1 (cols. 145-149); II, 14 (cols. 176-177); II, 17 (PG 26, col. 177); II, 40 (col. 232); III, 2 (cols. 324-325); III, 8 (cols. 336-337); III, 16 (cols. 353-358); III, 27-28 (PG 26, col. 692); III, 67 (cols. 464-468); Epist. Egyp. Lib., 9 (PG 25, cols. 557-560); 13 (PG 25, cols. 565569); 17 ( $P G$ 25, cols. 576-580). Sobre el particular, vid. C. KANNENGIESSER, Athanase d'Alexandrie évêque et écrivain (Paris 1983) pág. 124.

${ }^{53}$ Atanasio, Decret., 2 (H. G. OPITZ, Athanasius Werke [Berlin - Leipzig 1935 ss.] II, pág. 2); Or. Adv. Ar., I, 38 (PG 26, cols. 88-89); II, 17 (PG 26, col. 177); III, 27-28 ( $P G$ 26, col. 692). 
que los seguidores de esta herejía eran unos «nuevos judíos» que habían tomado prestados de la incrédula Israel su insensata ceguera y su corazón endurecido. Inspirados por Satanás para odiar a Cristo, se comportaban como los fariseos que desafiaron a Jesús al preguntarle por qué, siendo hombre, se hacía Dios ${ }^{54}$. Tomando, como de costumbre, a los judíos como término negativo de comparación, Atanasio conjetura que si los arrianos creyesen en las Escrituras, no rivalizarían más en maldad con los deicidas ${ }^{55}$. Tal es la simbiosis que asegura que existe entre judíos y arrianos que, forzando al máximo su argumentación, acusa también a los segundos de ser enemigos y asesinos de Cristo ${ }^{56}$.

No puede ignorarse que la feroz lucha por el control de la sede alejandrina y la extensión de la controversia a lo largo y ancho del mundo cristiano, contribuyeron a que el mito del filojudaísmo arriano se convirtiese pronto en un tópico dentro de la literatura antiarriana ${ }^{57}$. La imposición imperial de un obispo arriano en Alejandría y la política antinicena impulsada por Constancio II, terminaron por desatar la cólera en una parte de la jerarquía católica. Así, por ejemplo, Lucifer de Cagliari no dudó en defender con energía la causa de Atanasio, destacando por la agresividad con la que escribió

\footnotetext{
${ }^{54}$ Atanasio, Apol. fug., 9-10 (ed. J. M. SzYMUSIAK, Athanase d'Alexandrie. Deux apologies [Paris 1987] SC 56bis, págs. 194-198); Dionys., 3 (H. G. OPITZ, Athanasius Werke, II, págs. 47-48); Decret., 5 (H. G. OPITZ, Athanasius Werke, II, págs. 4-5).

${ }^{55}$ Atanasio, Apol. fug., 2 (J. M. SZYMUSiaK, Athanase d'Alexandrie, pág. 178).

${ }^{56}$ Atanasio, Ep. fest., 10, 9 (PG 26, col. 1402). Cfr. Or. adv. Ar., I, 3 (PG 26, col. 17). Vid. R. C. GREGG y D. E. GROH, Early Arianism, pág. 46, que se pronunciaron en contra de las reticencias de G. CH. STEAD («Rhetorical Method in Athanasius», Vigiliae Christianae 30 [1977] págs. 131-132) para aceptar una evidente conexión en Atanasio entre la negación de la divinidad del Hijo y la consideración de judíos y arrianos como enemigos conjuntos del credo católico.

${ }^{57}$ Gregorio de Elvira constituye una curiosa excepción, ya que en ningún momento implica a los judíos en su controversia contra el arrianismo. Como ha observado algún autor, «es un silencio sorprendente porque Gregorio profesó un antijudaísmo casi obsesivo»: J. FERNÁNDEZ UBIÑA, «La fe de Gregorio y la sociedad de Elvira», en La sociedad de la Bética. Contribuciones para su estudio, ed. C. GonZÁlez Román (Granada 1994) pág. 164.
} 
varios opúsculos contra el emperador herético. Aparte de aplicarle los calificativos más infamantes y de compararle de forma superlativa con los reyes más idólatras y los personajes más denigrantes de la Biblia ${ }^{58}$, Lucifer le acusó de haberse sometido a la peste arriana y, por tanto, de estar contagiado por la perfidia de los judíos a los que imitaba ${ }^{59}$. De esta forma, el cruel perseguidor estaba manchado a un mismo tiempo por la herejía y por el judaísmo. «Presta oídos -le dice-: nosotros que creemos que todos estos santísimos hombres asesinados por tu espada están en el Paraíso, hemos decidido dejarnos matar por ti, pues hemos comprobado que es mejor poseer el amor de Dios por todos los siglos que ser castigados contigo, imitador de Judas Iscariote y de los judíos» ${ }^{60}$. En un sentido muy similar, Hilario de Poitiers habla en el prefacio de su Opus Historicum del testimonio de la justicia y de las promesas divinas como un preciado regalo para el «confesor» y mártir que ha perecido a manos de los arrianos ${ }^{61}$. Según P. Smulders, la referencia en su argumentación a $M t 5,10-12$ debe ponerse en relación con un pasaje de su Comentario a Mateo ${ }^{62}$ en el que Hilario establece una clara vinculación entre los judíos, perseguidores de Cristo, y los

\footnotetext{
${ }^{58}$ Vid. F. HEInZ, «Invenies te esse hodie (D. Athan. II, 16). Constance II l'hérétique et les rois idolâtres chez Lucifer de Cagliari», en Rois et reines de la Bible au miroir des Pères (Strasbourg Cedex 1999) págs. 141-159. Cfr. R. P. C. HANSON, The Search for the Christian Doctrine, pág. 323.

${ }^{59}$ Lucifer de Cagliari, Moriendum esse pro dei filio, 2, 68-73 (ed. V. UGENTI, Luciferi Calaritani De regibus apostaticis et Moriundum esse pro dei filio [Lecce 1980] págs. 43-44) y 10, $703-707$ (V. UGENTI, pág. 66); De regibus apostaticis, 12, 964-965 (V. UGENTI, pág. 38).

${ }^{60}$ Lucifer de Cagliari, Moriendum esse pro dei filio, 2, 68-73 (V. UGENTI, pág. 117): illos omnes beatissimos tuo mactatos gladio in paradiso esse qui credimus, crede mihi quod a te statuerimus interfici, quia et melius esse uiderimus in omnia aeua deum habere amatorem quam tecum Iudas Scariothae atque Indaeorum imitatore puniri.

${ }^{61}$ Hilario de Poitiers, Opus Historicum, praef., II, 3. Vid. P. SMULDERS, Hilary of Poitiers' Preface to His Opus Historicuam. Translation and Commentary (Leiden 1995) pág. 58, n. 170.

${ }^{62}$ Hilario de Poitiers, Comm. in Matt., 10, 12, 1 (ed. J. Dolgnon, Hilaire de Poitiers. Sur Matthieu [Paris 1978] SC, 254, pág. 230).
} 
herejes arrianos, perseguidores de los católicos ${ }^{63}$. Así pues, la iniquidad arriana quedaba reforzada por su íntima relación con la religión judía, término negativo de comparación por antonomasia. Hilario de Poitiers se lo recrimina directamente al hereje de la siguiente forma: «Mira cómo te has introducido en la compañía impía de los judíos al negar al Hijo de Dios» ${ }^{64}$.

Como cabía esperar, el mito no tardaría en incorporarse eficazmente a la tradición del género literario Adversus Iudaeos. Juan Crisóstomo, cuya dialéctica antijudía es probablemente la más agresiva de todos los padres de la Iglesia, no dudó en denunciar con especial atención la perniciosa relación que existía entre judíos y anomeos, una de las ramas radicales del arrianismo antioqueno ${ }^{65}$. Apenas comenzado su primer sermón contra los judíos, advierte a su auditorio de los peligros que entrañaba la desviación judaizante de los arrianos, estrechamente ligados al credo judaico por el vínculo de una misma incredulidad, es decir, el rechazo común de la divinidad de Cristo:

[...] Puesto que la impiedad de los anomeos es muy parecida a la de los judíos, también nuestra batalla diaria se presenta muy similar a la dirigida contra aquéllos. La acusación que formulan los judíos es la misma que la de los anomeos. ¿De qué acusación se trata?, pues del hecho de que Cristo declarase que Dios era su Padre y de que se considerase a sí mismo igual a Dios. Esta acusación también la formulan los anomeos, es más, ni siquiera la formulan, sino que eliminan direc-

${ }^{63}$ P. SMulders, Hilary of Poitiers' Preface, págs. 116-117.

${ }^{64}$ Hilario de Poitiers, Trin., VI, 50 (ed. L. LADARIA, San Hilario de Poitiers. La Trinidad [Madrid 1986] pág. 295): [...] Et vide in quod te, negando filium Dei, Iudaicae impietatis consortium miscuisti [...]. Vid. H. SCHRECKENBERG, Die christlichen Adversus-Judaeos-Texte, pág. 280. Cfr. Quodvultdeus de Cartago, Adv. quinq. haer., 4, 39 (ed. R. BRAUN, en CCL 60, pág. 275): [...] Audiat adhuc Iudaeus quid per prophetam dominus dicat, audiat Arrianus, aundiant et omnes qui filium dei aut non esse aut esse minorem dicunt [...] (vid. R. GoNZÁLEZ SALINERO, «The Anti-Judaism of Quodvultdeus», págs. 456-457).

${ }^{65}$ Vid. M. Simonetti, La crisi ariana, pág. 584; M. WiLES, Archetypal Heresy, pág. 31 . 
tamente el nombre de Cristo y su significado, si no materialmente, sí al menos en su mente y en su ánimo $[\ldots]^{66}$.

Gregorio de Nazianzo ofrece una explicación similar sobre la supuesta interferencia lógica que existía entre judíos y arrianos. Para él, tres males teológicos aquejaban a la doctrina cristiana en su época: el ateísmo, el judaísmo y el politeísmo. Cada uno de ellos vendría representado por determinados protagonistas: el primero por Sabelio, el segundo por Arrio de Alejandría, y el último por los que se mostraban demasiado ortodoxos entre los propios cristianos. Si Sabelio había definido a Dios como un único ser carente de diferentes naturalezas y los «ultraortodoxos» veían en la Trinidad una pluralidad de poderes típica de la cultura griega, la «locura» de Arrio

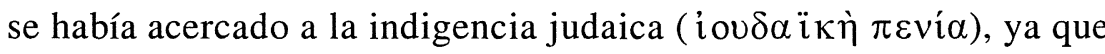
propugnaba la introducción de la envidia ( $\varphi$ Өóvoৎ) en el seno de la naturaleza divina, reservando ésta solamente al Padre ingénito $(\dot{\alpha} \gamma \dot{\varepsilon} \nu \vee \eta \tau o \varsigma){ }^{67}$. El punto de conexión entre judíos y arrianos sería, pues, la negación compartida del trinitarismo niceno, razón por la

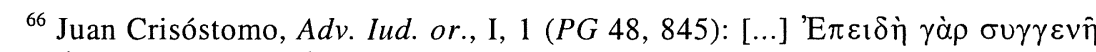

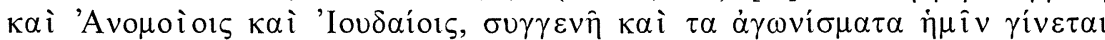

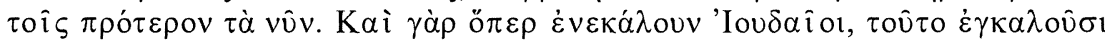

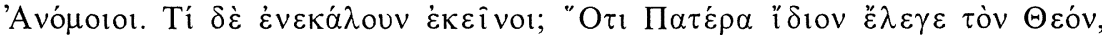

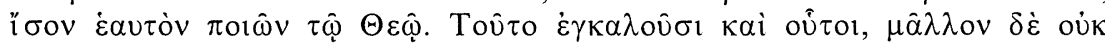

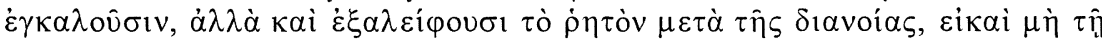
$\chi \varepsilon ı \rho^{\prime}, \dot{\alpha} \lambda \lambda \dot{\alpha} \tau \hat{\eta} \gamma \nu \omega ́ \mu \eta$. Cfr. Gregorio de Nisa, Contr. Eunom., 9 (ed. W. JAEGER, Contra Eunomium libri. Pars altera [Leiden 1960] págs. 217-218). Vid. M. PAVAN, «I cristiani e il mondo ebraico nell'età di Teodosio "il Grande"», Annali della Facoltà di Lettere e Filosofia dell'Università di Perugia 3 (1965-1966) págs. 466-467; R. L. WILKEN, John Chrysostom and the Jews. Rhetoric and Reality in the Late $4^{\text {th }}$ Century (Berkeley 1983) págs. 34-35 y 117; M. Simon, Verus Israel, pág. 486, n. 81 .

${ }^{67}$ Gregorio de Nazianzo, Orat., II, 37 (ed. CL. MoresChini, Gregorio di

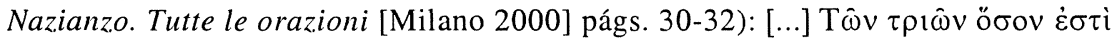

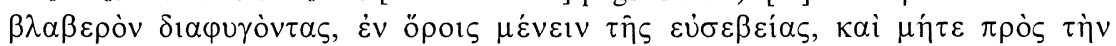

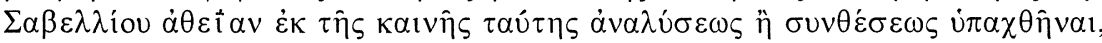

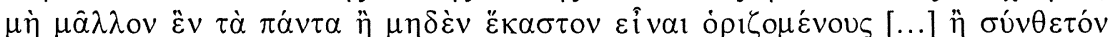

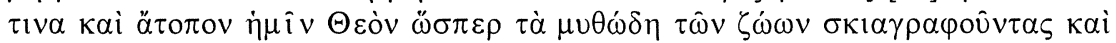

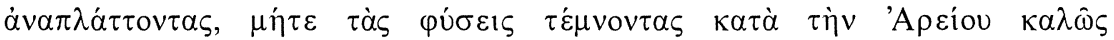

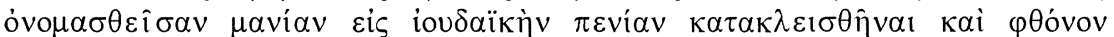

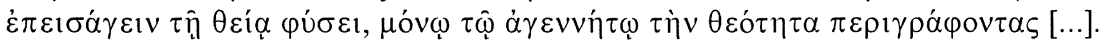


que Gregorio de Nazianzo hizo de ambos un único adversario ${ }^{68}$. En esta misma dirección se pronunciaría años más tarde el autor anónimo del Dialogus Athanasii et Zacchaei, para quien la ofensiva dialéctica contra los arrianos implicaba al mismo tiempo una implacable lucha contra los judíos ${ }^{69}$. Incluso, era tal la simbiosis que Jerónimo creía ver entre los judíos y los arrianos que llegó a equiparar a la «Sinagoga del Anticristo» (y eventualmente al templo pagano) con «una iglesia sostenida por un arriano» ${ }^{70}$.

En Occidente, Ambrosio de Milán manifiesta igualmente su repulsa hacia el arrianismo estableciendo en el plano doctrinal un acercamiento de la herejía de Arrio a la religión judía, en una especie de reductio ad symbolum Iudaicum, con el único fin de desacreditar a los arrianos, por los que sentía una fuerte aversión ${ }^{71}$. En una carta que escribe a su hermana en el año 386 para informarla del descubrimiento de las reliquias de los mártires Gervasio y Protasio, aporta algunos detalles del sermón que pronunció contra los arrianos que se habían mofado de los milagros atribuidos a ambos santos. Al parecer, dicho sermón giraba en torno a la perversa convergencia entre la incredulidad de los judíos ante los milagros de Cristo y la falta de honestidad de los arrianos al no admitir como ciertas las maravillas operadas por intercesión de los mártires ${ }^{72}$, nada extraño si se tiene en cuenta que tanto unos como otros rechazaban el misterio de la Trinidad ${ }^{73}$. Si en

${ }^{68}$ Vid. M. PAVAN, «I cristiani e il mondo ebraico», págs. 465-466.

${ }^{69}$ Vid. A. KÜLZER, Disputationes Graecae contra Iudaeos. Untersuchungen zur byzantinischen antijuidischen Dialogliteratur und ihrem Judenbild (Stuttgart Leipzig 1999) pág. 105.

${ }^{70}$ Jerónimo, Alt. Lucif., 2 (PL 23, cols. 164-165). Vid. R. GonZÁlez SALINERO, Biblia y polémica antijudía en Jerónimo (Madrid 2003) pág. 128.

${ }^{71}$ M. PAVAN, «I cristiani e il mondo ebraico», págs. 470-471.

${ }^{72}$ Ambrosio, Epist., 77, 18 (ed. M. ZELZER, en CSEL 82, 3, pág. 137 = Epist., 22, 18: PL 16, col. 1068): Detestabilior istorum quam Iudaeorum pertinacia; illi cum dubitarent uel parentes interrogabant, isti occulte interrogant, palam negant iam non operi increduli sed auctori $[\ldots]$.

${ }^{73}$ Ambrosio, Epist., 77, 21-22 (CSEL 82, 3, págs. 138-139 = Epist., 22, 21-22: $P L$ 16, cols. 1068-1069). 
algunas ocasiones Ambrosio afirmaba que los judíos eran menos detestables que los arrianos ${ }^{74}$, en otras los considera en cambio graviores inimici que los herejes por el hecho de que ex amicis inimici facti sunt ${ }^{75}$. En cualquier caso, no existe evidencia alguna que permita suponer, como hizo L. Cracco Ruggini ${ }^{76}$, que hubo un momento en que Ambrosio mantuvo «buenas» relaciones con los judíos antes de que se aliasen con los arrianos y los paganos para apoyar al usurpador Máximo ${ }^{77}$. De hecho, la actitud agresiva que desde un principio demuestra tener hacia ellos haría imposibles tales relaciones ${ }^{78}$. Tampoco su repulsa a la ignominiosa unión de judíos y arrianos dependió de esa supuesta alianza contra Máximo, ya que no dudó en ningún momento de que, debido a su afinidad doctrinal, dicha unión existiera con anterioridad a esos acontecimientos ${ }^{79}$. En

${ }^{74}$ Ambrosio, Serm. contr. Aux. (= Epist., 75a), 31 (CSEL 82, 3, pág. $103=P L$ 16, col. 1016): Et tamen videte quanto peiores Ariani sunt, quam Iudaei. Cfr. Epist., 75, 13 (CSEL 82, 3, págs. 78-79 = Epist., 21, 13: PL 16, col. 1005); Fid. Grat., III, 38 (PL 16, col. 597). Cfr. Lucifer de Cagliari, De non conveniendo cum haereticis ( $P L$ 13, cols. 767 ss.); Cirilo de Alejandría, In Ioann., 7 (PG 74, cols. 25-26). Vid. H. SCHRECKENBERG, Die christlichen Adversus-Judaeos-Texte, pág. 375.

${ }^{75}$ Ambrosio, Exp. psalm., 118, 13, 6 (ed. M. PetSCHENig, en CSEL 62, págs. 284-285). Vid. G. FigueroA, The Church and the Synagogue in St. Ambrose (Washington 1949) pág. XXI; M. PAVAN, «I cristiani e il mondo ebraico», pág. 471; R. GONZÁlez SAlinero, El antijudaísmo cristiano, pág. 146.

${ }^{76}$ L. CRACCo RUgGinI, «Ambrogio e le opposizioni anticattoliche fra il 383 e il 390», Augustinianum 14 (1974) especialmente págs. 438 y 442.

${ }^{77}$ Según Ambrosio, el usurpador Máximo ordenó a los católicos que habían incendiado una sinagoga en Roma la reconstrucción del edificio, lo que provocó la animadversión de la comunidad católica de la ciudad, que le calificó de judío: Ambrosio, Epist., 74, 23 (CSEL 82, 3, págs. 68-69 = Epist., 40, 23: PL 16, col. 1109). Vid. R. GONZÁlEz SALINERo, El antijudaísmo cristiano, pág. 231.

${ }^{78}$ N. B. MCLYNN, Ambrose of Milan. Church and Court in a Christian Capital (Berkeley 1994) pág. 304.

${ }^{79}$ Ahora bien, esto no fue óbice para que Ambrosio utilizase el mito del filojudaísmo arriano como un argumento más en su denodada lucha contra esta fuerte herejía que, con la entrada masiva de los godos en el ejército romano estacionado en Sirmio y Milán, fue adquiriendo cada vez más fuerza en el norte de Italia. Dentro de este contexto, Ambrosio no dudó en utilizar todos los recursos dialécticos que estuvieron a su alcance para defender la res Romana de la barbarie herética. La 
este sentido, en la Apologia David altera, obra atribuida al obispo de Milán, se reconocía una vez más que el arriano no difería mucho del judío ${ }^{80}$.

Para Cromacio, obispo de Aquileya, los judíos no representaban para su comunidad un peligro tan grande como el de los arrianos. Sin embargo, como ya hicieran Ambrosio y otros padres de la Iglesia, arremete contra la impiedad de estos últimos poniéndola en estrecha relación con la perfidia judaica, pues tanto herejes como judíos rechazaban la divinidad de Cristo ${ }^{81}$. En uno de sus sermones afirma que «la Sinagoga se ha convertido en el albergue de toda infidelidad y de todo error» ${ }^{82}$. Según él, los judíos expulsados del Templo con un látigo de cuerdas prefiguran a todos los que niegan la Trinidad y especialmente a los herejes arrianos: «esa triple cuerda constituye sin duda la figura de la Trinidad, que no se puede romper porque la fe en la Trinidad es incorruptible. Es la misma fe que todos los herejes tratan de corromper; pero sólo han conseguido corromperse ellos mismos» ${ }^{83}$. A su vez, Gregorio de Tours recuperaría en

inmediata adopción de la nueva liturgia latina, símbolo cristiano de la Romanitas, supuso igualmente un valioso instrumento para repeler la influencia de los arrianos. Sobre el particular, vid. M. K. LAFFERTY, «Translating Faith from Greek to Latin: Romanitas and Christianitas in Late Fourth-Century Rome and Milan», Journal of Early Christian Studies 11 (2003) págs. 35-49 y 53-55.

${ }^{80}$ Apol. David alt., 4, 26 (ed. C. SCHENKL, en CSEL 32, 2, pág. 374): [...] de Arianis, qui non multum a Iudaeis differunt [...]. Vid. H. SCHRECKENBERG, Die christlichen Adversus-Judaeos-Texte, pág. 303; R. GONZÁLEZ SAlinERO, El antijudaísmo cristiano, pág. 149.

${ }^{81}$ Cromacio de Aquileya, Serm., 28, 2 (ed. J. Lemarié, Chromace d'Antioquée. Sermons [Paris 1969-1971] SC 164, pág. 118).

${ }^{82}$ Cromacio de Aquileya, Serm., 32, 3 (J. Lemarié, SC 164, pág. 164): [...] Diversorium autem recte synagoga intellegitur, quia sicuti ad diversorium gentes diversae quidem applicant, ita synagoga diversorium facta est omnis infidelitatis et totius erroris, unde Christus illic locum invenire non potuit [...].

${ }^{83}$ Cromacio de Aquileya, Serm., 4, 1 (J. LemarIÉ, SC 154, pág. 160): [...] In sparto triplici Trinitas sine dubio demonstratur, quod rumpi non potest, quia incorrupta fides est Trinitatis. Quam fidem frequenter haeretici corrumpere conati sunt, quantum in ipsis est; sed et seipsos corruperunt [...]. Vid. F. THELAMON, «Les vaines illusions des Juifs incrédules selon Chromace et Rufin d'Aquilée», en 
la segunda mitad del siglo VI la idea de que judíos y arrianos constituían un único enemigo para la Iglesia. Para él, la íntima relación que les unía se pondría de manifiesto con la colaboración arriana en la llegada del Anticristo, una figura eminentemente judía ${ }^{84}$. Como ha señalado A. Keely, la intencionada asociación de ambas «desviaciones» serviría a Gregorio de Tours como una especie de «agents of differentiation» respecto al cristianismo católico, única religión verdadera ${ }^{85}$.

Sin embargo, esta insistente asociación doctrinal de los arrianos con el judaísmo, que, como hemos visto, se había extendido ampliamente en la literatura antiarriana hasta convertirse en un lugar común, no respondía en realidad a razones objetivas. R. Lorenz demostró convincentemente que la doctrina de Arrio no sufrió influencias directas ni tuvo dependencias del judaísmo ${ }^{86}$. Su doble noción de Dios como årxh (origen o principio creador) del Hijo y de Éste como årxh del cosmos, no tiene raíz judía ni judeocristiana. No parece que su teoría de la existencia del segundo principio, creado por el Padre de una sustancia ajena a su propia naturaleza y mediador entre Él mismo y la creación, recogiera herencia alguna procedente de dichas tradiciones. La ausencia en el arrianismo de cualquier especulación cosmológico-apocalíptica en relación al segundo principio, imposibilitaría cualquier tipo de conexión con la existencia de seres «intermediarios» en el judaísmo tardío ${ }^{87}$. En el libro de Henoch, por ejemplo, podemos constatar que la figura del Mesías (o la persona del Hijo) no poseía la condición de «mediador» de la

\footnotetext{
Les chrétiens face à leurs adversaires dans l'Occident latin au IV siècle, ed. J.-M. POINSOTTE (Rouen 2001) págs. 99 y 111-112.

${ }^{84}$ Gregorio de Tours, Hist., 1, praef. (ed. B. KRUSCH y W. LEvison, en $M G H$, rer. Mer., I, 1, págs. 4-5).

${ }^{85}$ Vid. A. KEELY, «Arians and Jews in the Histories of Gregory of Tours», Journal of Medieval History 23 (1997) especialmente págs. 103-104 y 114-115.

${ }^{86}$ R. LORENZ, Arius judaizans? Untersuchungen zur dogmengeschichtlichen. Einordnung des Arius (Göttingen 1979) pág. 224.

${ }^{87}$ R. LOREnZ, Arius judaizans?, págs. 140 y 154.
} 
creación, sino la que le confería su función puramente escatológica ${ }^{88}$. Por otro lado, la ortodoxia rabínica se mostró completamente contraria a la aceptación de un segundo principio al lado de Dios. Para el judaísmo antiguo la cuestión de las hipóstasis estaba únicamente relacionada con las «funciones cosmológicas» en la medida en que derivaban del propio Dios, como la Sabiduría, la Torá o los ángeles ${ }^{89}$. La distancia con el pensamiento de Arrio era, pues, considerable. $\mathrm{Si}$, aun así, en su doctrina aparecen influencias exegéticas judías, éstas procedieron claramente de la tradición de la escuela alejandrina y, especialmente, de Orígenes, profundo conocedor de la ciencia rabínica ${ }^{90}$. Aunque no existen dudas de que, como ya afirmara Gregorio de Nisa respecto a Eunomio ${ }^{91}$, Arrio recibió una indeleble impronta de Filón, fue en la misma medida seducido por el platonismo ${ }^{92}$. Sin embargo, algún autor ha sobrevalorado estas «reminiscencias» judías o judeocristianas, si no en el pensamiento del propio Arrio, sí al menos en el desarrollado por el neo-arrianismo, especialmente en los aspectos relacionados con la liturgia eucarística. Th. A. Kopecek llama la atención, por ejemplo, sobre la

${ }^{88}$ Libro 1 de Henoch, 61, 5 (trad. F. CORRIEnTE y A. PIÑERO, Apócrifos del Antiguo Testamento, IV. Ciclo de Henoch [Madrid 1984] pág. 83). Cfr. 45, 4 (p. 71); 51, 3 (p. 75); 62, 2 (p. 85). Vid. R. LoRENZ, Arius judaizans?, pág. 144.

${ }^{89} \mathrm{Vid}$. G. FOOT-MOORE, Judaism in the First Centuries of Christian Era (Cambridge Mass. 1927) I, págs. 261 ss.

${ }^{90}$ R. LoRenZ, Arius judaizans?, pág. 179. Cfr. TH. BÖHM, Die Christologie des Arius, págs. 227 ss. También es cierto que no puede considerarse al arrianismo tan sólo como una especie de subordinacionismo radical respecto a la línea de la teología origenista tradicional (R. LORENZ, Arius judaizans?, págs. 211-224). Al respecto vid. las oportunas observaciones de $\mathrm{CH}$. KANNENGIESSER, «Arius and the Arians», Theological Studies 44 (1983) (= en CH. KANNENGIESSER, Arius and Athanasius. Two Alexandrian Theologians [Hampshire 1991]) págs. 472-473. G. STEMBERGER (Jews and Christians, pág. 74, n. 73) piensa, no obstante, que el origenismo de Arrio fue mucho más decisivo que la cuestión de la hipotética influencia judía en la controversia antiarriana.

${ }^{91}$ R. P. C. HANSON, The Search for the Christian Doctrine, págs. 631 y 636.

${ }^{92}$ G. CH. STEAD, «The Platonism of Arius», Journal of Theological Studies 15 (1964) especialmente págs. 19 y 24; TH. BÖHM, Die Christologie des Arius, págs. $157-158$ y 164. 
influencia de la observancia y celebración del sábado en alguna de las oraciones recogidas en las Constituciones Apostólicas, influencia que pudo haber encontrado su cauce más directo de penetración a partir de la lectura del Antiguo Testamento según la versión de Áquila y no de la Septuaginta ${ }^{93}$. Hay que tener en cuenta, en todo caso, que el influjo judío sobre el cristianismo en general, incluso en mayor medida que en el arrianismo, fue mucho más fuerte de lo que revelan los estudios tradicionales. No podía haber sido de otra forma, habida cuenta de que los primeros creyentes procedentes del judaísmo actuaron como los verdaderos maestros teológicos del cristianismo de origen gentil. Como ha demostrado O. Skarsaune, dicha conexión se haría evidente sobre todo en el desarrollo del canon, en los primeros estadios de la cristología, en la conversión y el bautismo, en el culto, en el calendario litúrgico y (como se evidencia en el caso de las Constituciones Apostólicas) en la liturgia eucarística ${ }^{94}$.

Conscientes de la acusación de filojudaísmo lanzada tan profusamente contra ellos por la ortodoxia, algunos autores arrianos han dejado testimonios, sin duda muy escasos, que permiten vislumbrar que trataron de desmentir lo que consideraban una completa e intolerable falsedad. A partir de las citas de Atanasio, G. Ch. Stead «reconstruye» lo que pudo ser una respuesta lógica (posterior al 360) de los arrianos a las «mentiras» que los católicos divulgaban en su contra ${ }^{95}$. Según este autor moderno, en el trasfondo de las palabras de Atanasio podría adivinarse una hipotética réplica a la acusación «de formar parte de los judíos, de Caifás y de Pablo de Samosata» ${ }^{96}$. En efecto, tanto

\footnotetext{
${ }^{93}$ TH. A. KOPECEK, «Neo-Arian Religion: The Evidence of the Apostolic Constitutions», en Arianism. Historical and Theological Reassessments, ed. R. C. GREGG (Phildelphia 1985) págs. 155-157.

${ }^{94}$ Vid. O. SKARSAUNE, In the Shadow of the Temple: Jewish Influences on Early Christianity (Downers Grove, Illinois 2002).

${ }^{95}$ Atanasio, Or. contr. Ar., I, 38 (PG 26, cols. 88-89); Decret., 10 (H. G. OPITZ, Athanasius Werke, II, 1.1, pág. 9); Dionys., 3 (H. G. OPITZ, Athanasius Werke, II, 1.1 , págs. 47-48).

${ }^{96}$ La propuesta de G. CH. STEAD era la siguiente: «But I shall not fail to expose the falsity of those words which you misuse against us. For in the first place you
} 
Alejandro como Atanasio invocaron en numerosas ocasiones el nombre maldito del judaizante Pablo de Samosata (obispo de Antioquía en la segunda mitad del siglo III) para restar credibilidad a quienes, como los arrianos, se acusaba de ser sus imitadores ${ }^{97}$. Poco importaba que, en el fondo, supiesen que no existía relación alguna entre ellos, ya que el fin último de tal acusación era que, por medio de este hábil proceso de asociación, los herejes absorbieran la repulsión que inspiraba la figura de Pablo de Samosata y quedara al descubierto la depravación de los arrianos ${ }^{98}$. De hecho, en el Concilio de Sirmio, éstos dieron muestra de su repulsa al judaísmo al declarar que las palabras de Isaías 44, 6 («Yo soy el primero y el último, no hay otro dios fuera de mí») no debían interpretarse «a la manera judía» como una prueba para negar a Cristo ${ }^{99}$. Asterio el Sofista rechazaba tajantemente la creencia de que Jesús fuese solamente un

traduce us as if we had said that Christ was a mere man; and you tax us with taking the part of the Jews and of Caiphas and of Paul the Samosatene»: G. CH. STEAD, «The Arian Controversy: A New Perspective», en Doctrine and Philosophy in Early Christianity. Arius, Athanasius, Augustine, ed. G. CH. STEAD (Aldershot $2000)$ cap. VIII, pág. 53 (= en H. EISENBERGER, 'EPMHNEYMATA

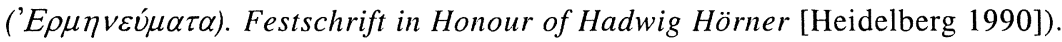

${ }^{97}$ Alejandro de Alejandría, Epist. ad Alex., 9 (ed. H. G. OpITZ, Athanasius Werke, III, 1, doc. 14, pág. 25, 35); Atanasio, Decret., 10 (H. G. OPITZ, Athanasius Werke, II, 1.1, pág. 9) y 24 (H. G. OPITZ, Athanasius Werke, II, 1.1, págs. 19-20); Dionys., 3 (H. G. OPITZ, Athanasius Werke, II, 1.1, págs. 47-48); Or. contr. Ar., I, 13 ( $P G$ 26, cols. 37-40); I, 37-38 (PG 26, cols. 88-91); II, 17 ( $P G$ 26, col. 177); Hist. Ar., 71 (H. G. OpITZ, Athanasius Werke, II, 1.1, págs. 221-222). Cfr. Juan Crisóstomo, Exp. in psalm., 109, 1 (PG 55, cols. 264-265); Adv. Iud. or., I, 1 ( $P G$ 48, col. 845); De sacerd., 4, 4 (ed. A.-M. MALiNGREY, Sur le sacerdoce [Paris, 1980] SC 272, pág. 258). Vid. J. JUSTER, Les Juifs dans l'Empire romain, I, pág. 284, n. 1; M. Simon, Verus Israel, pág. 96. C. KANNENGIESSER (Athanase d'Alexandrie, pág. 124) aporta una lista de los lugares en que Atanasio vincula a los arrianos con diferentes grupos: seguidores de Pablo de Samosata, judíos, marcionitas, maniqueos, gnósticos, frigianos, etc.

${ }^{98}$ Vid. R. C. GregG y D. E. GroH, Early Arianism, pág. 164.

${ }^{99}$ Anatema 11. Cfr. Anatema 14 (Hilario, 13). Vid. CH. J. Hefele, A History of the Canons of the Councils of the Church from the Original Documents, II: A.D. 326 to A. D. 429 (Edinburgh 1896) pág. 195. 


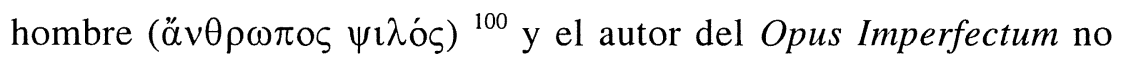
veía posible la acusación de deicidio contra los judíos (de la que no cabía duda alguna) si se aceptaba dicha falsedad ${ }^{101}$. Por su parte, en su debate con Agustín de Hipona, el obispo Maximino le dirige las siguientes palabras:

Dices que hay un solo Dios. Mira si el Padre, el Hijo y el Espíritu son un solo Dios, o si solo el Padre ha de ser considerado único Dios, cuyo Hijo, Cristo, es nuestro Dios. ¿Nos animas a confesar, según la costumbre judía, un solo Dios? ¿O será preferible confesar que, por la sujeción del Hijo, conforme lo profesa la fe cristiana, hay un solo Dios, cuyo Hijo, como hemos dicho, es nuestro Dios? ${ }^{102}$.

En realidad, tanto Agustín como el resto de los autores antiarrianos supieron discernir las evidentes diferencias que existían entre la doctrina «herética» y la religión judía. Así lo expresaba el obispo de Hipona en su Tratado sobre el Evangelio de Juan:

[...] Mirad cómo los judíos ven lo que los arrianos no quieren ver. Los arrianos dicen que el Hijo no es igual al Padre, y de aquí la herejía que aflige a la Iglesia. Ved cómo hasta los mismos ciegos y los

\footnotetext{
${ }^{100}$ Asterio, Comm. psalm., XXXI, 4-8 (M. RiCHARD, Asterii Sophistae commentariorum in psalmos [Oslo 1956] págs. 243-245).

${ }^{101}$ Op. Imp., col. 889: [...] Quando vides eos dicentes, purum hominem crucifixum et anima, et corpore, non Deum in corpore solum, in quo nulla esset divinitas: scito quoniam implent mensuram Iudaeorum patrum suorum [...] Si enim homo purus est passus, dimitto: quia nos mors hominis, non Dei salvavit. Sed dico, Iudaei tale peccatum fecerunt, quale facit qui hominem occidit, non Deum. Vid. R. P. C HANSON, «Arian Doctrine of the Incarnation», en Arianism: Historical and Theological Reassessments, ed. R. C. GREGG (Philaelphia 1985) págs. 190 y 202; ID., The Search for the Christian Doctrine, págs. 120-121.

${ }^{102}$ Agustín, Altercatio cum Maximino arionorum episcopo, 15, 23 (ed. bilingüe

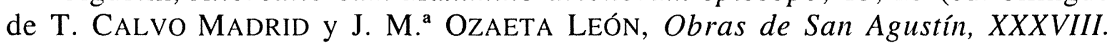
Escritos contra los arrianos y otros herejes [Madrid 1990] BAC 512, pág. 411): Dicis quod unus est Deus. Astrue, si Pater et Filius et Spiritus sanctus unus est Deus, an solus Pater unus Deus dicendus est, cuius Filius Christus noster est Deus. Iudaico more hortaris nos profiteri unum Deum? An de subiectione Filii potius, secundum quod habet fides christiana, ostenditur unus esse Deus, cuius filius noster est Deus, ut diximus? Sobre este debate sostenido por Agustín y Maximino hacia el año 427/428, vid. W. A. SUMrULD, Augustine and the Arians. The Bishop of Hippo's Encounters with Ulfilan Arianism (Selinsgrove - London 1994) especialmente págs. 91 ss.
} 
mismos que mataron a Cristo entendieron, sin embargo, el sentido de las palabras de Cristo. No vieron que él era Cristo ni que era Hijo de Dios; mas, a pesar de eso, vieron en aquellas palabras [...] que tenía que ser igual a Dios [...] y que se hacía igual a Dios. Pero no era Él quien se hacía igual a Dios. Era Dios quien le había engendrado igual a Él $[\ldots]^{103}$.

A pesar de que tanto arrianos como judíos negaban (aunque por razones diversas) el misterio de la Trinidad, Ambrosio diferenciaba a menudo las doctrinas que caracterizaban a cada uno de ellos ${ }^{104}$. Sin embargo, no renunció nunca a ponerlos en mutua correlación, con la intención de reducirlos a un mismo denominador. Así pues, por medio de una especie de argumento ad abundantiam, el implacable ataque que dirige contra los arrianos cobra mayor fuerza al vincularlos a la maldad y perversión de judíos y paganos ${ }^{105}$. De hecho, fue muy habitual que en la literatura polémica contra judíos,

${ }^{103}$ Agustín, Tract. Ioann., 17, 16 (ed. bilingüe de T. PriETo y V. RABAnAL, Obras completas de San Agustín, XIII-XIV. Tratados sobre el Evangelio de San Juan (Madrid 1955-1957) BAC 139 y 165, I, págs. 466-467): Ecce intellegunt Iudaei quod non intellegunt Ariani. Ariani quippe inaequalem Patri Filium dicunt, et inde haeresis est pulsa de Ecclesia. Ecce ipsi caeci, ipsi interfectores Christi, intellexerunt tamen verba Christi. Non intellexerunt esse Christum, nec eum intellexerunt Filium Dei, sed tamen intellexerunt [...] aequalis esset Deo [...] non ipse se faciebat aequalem, sed ille illum genuerat aequalem [...]. Cfr. Tract. Ioann., 48, 8 (T. PRIETO y V. RABANAL, Obras completas, II, págs. 200-201). Sobre el particular, vid. S. GONZÁLEZ, La preocupación arriana en la predicación de San Agustín (Valladolid 1989) págs. 97-102.

${ }^{104}$ Ambrosio, Fid. Grat., III, 37-38 (PL 16, cols. 596-597). Cfr. Serm. contr. Aux. (= Epist., 75a), 31 (CSEL 82, 3, pág. $103=P L$ 16, col. 1016). Vid. M. PAVAN, «I cristiani e il mondo ebraico», pág. 468.

${ }^{105}$ M. PAVAN, «I cristiani e il mondo ebraico», pág. 469. Según Atanasio, el arrianismo se identifica en un sentido con el monoteísmo radical del judaísmo (al negar la Trinidad) y, en otro, con el politeísmo (al individualizar y jerarquizar las Personas Divinas). De hecho, las acusaciones de que los arrianos no eran mejores que los judíos se alternan con las que les igualaban a los paganos (Atanasio, Or. contr. Ar., III, 67: PG 26, cols. 464-468): vid. M. WILES, Archetypal Heresy, pág. 8. En un sentido muy similar, Teodoreto de Ciro, In epist. Paul. (PG 82, col. 289): vid. J.-N. GUINOT, «Les fondements scripturaires de la polémique entre Juifs et chrétiens dans les commentaires de Théodoret de Cyr», Annali di Storia dell'Esegesi 14 (1997) págs. 168-169. 
herejes y paganos, todos ellos aparezcan como enemigos que mantienen entre sí puntos en común, especialmente su perversión y pertinaz oposición a la verdadera fe católica ${ }^{106}$. Por ello, no es extraño que, por ejemplo, el autor anónimo de una obra como las Consultationes Zacchaei christiani et Apollonii philosophi (traducción latina de un hipotético diálogo mantenido en griego entre un cristiano y un pagano) preste atención en su segunda parte a la polémica contra los judíos (capítulos 4-10) y los herejes: maniqueos, marcionitas, fotinianos, sabelianos, patripasianos, arrianos y novacianos (capítulos 11-18) ${ }^{107}$. Con la intención catequética de combatir a un mismo tiempo a los enemigos de la Iglesia, Cirilo de Jerusalén pone igualmente en el mismo plano a judíos, arrianos, maniqueos y sabelianos ${ }^{108}$; y Agustín añade además a los fotinianos, a los donatistas y a cuantos pertenecían a las diversas sectas que laceraban la unidad de los cristianos ${ }^{109}$. En este sentido, Arnobio el Joven consideraba el error en la fe como impia incredulitas, opuesta a la fides catholica de los iusti credentes, que, en cuanto tales, ostentaban junto a los santos la condición de vivi gracias a la muerte y resurrección de Cristo. En cambio, los increduli (equiparados a los iniusti, gentiles, Iudaei y haeretici) permanecían, sin apenas percibirlo, como mortui en vida ${ }^{110}$. Igual de vana sería la doctrina de unos y de otros, razón

\footnotetext{
${ }^{106}$ Vid. L. CRACCO RUGGINI, «Tolleranza e intolleranza nella società tardoantica: il caso degli ebrei», Ricerche di Storia Sociale e Religiosa 23 (1983) pág. 30; R. GONZÁlEZ SALINERo, El antijudaísmo cristiano, págs. 72 y 147-150.

${ }^{107}$ Vid. H. SChreCKenBerg, Die christlichen Adversus-Judaeos-Texte, pág. 331; A. KÜLZER, Disputationes Graecae contra Iudaeos, pág. 84.

${ }^{108}$ Cirilo de Jerusalén, Catech., VI, $32-36$ (PG 33, cols. 596-604); VIII, 1 (PG 33, col. 625); XII, 27 (PG 33, col. 760). R. C. GREGG, «Cyril of Jerusalem and the Arians», en Arianism. Historical and Theological Reassessments, ed. R. C. GREGG (Philadelphia 1985) pág. 93.

${ }^{109}$ Vid. S. GONZÁLEZ, La preocupación arriana, pág. 136. Cfr. H. SCHRECKENBERG, Die christlichen Adversus-Judaeos-Texte, págs. 280 y 293, respecto a Zenón de Verona y Basilio de Cesarea.

${ }^{110}$ Arnobio el Joven, Confl. Arn. Ser., IV, 7, 1-3 (F. GoRI, Arnobio il Giovane. Disputa tra Arnobio e Serapione [Torino 1993] pág. $238=P L 53$, col. 308). Cfr. I, 3, 2-13 (p. $64=P L 53$, cols. 242-243); II, 2, 26-29 (p. $136=P L 53$, col. 274); IV, 12, $8-27$ (págs. 260-262 = PL 53, col. 320). Vid. C. PIFARRÉ, Arnobio el Joven y la cristología del «Conflictus» (Barcelona 1988) págs. 91 y 114-115.
} 
por la que Jerónimo asigna tanto a los herejes (especialmente arrianos) como a los judíos, la maldición proferida por Jeremías (17, 5: «Maldito sea aquel que fía en hombre»), ya que todos ellos compartían el mismo error de no reconocer la naturaleza divina de Cristo:

[...] Se dice de los judíos y de los herejes que depositan su esperanza en un hombre, es decir, en su Cristo, que, según creen ellos, no ha de venir como hijo de Dios, sino como un simple hombre $[\ldots]^{11}$.

Por tanto, podría afirmarse que la asunción y divulgación del mito del filojudaísmo arriano cumplieron en los autores católicos una función meramente polémica. No cabe duda de que la asociación de ciertas ideas teológicas con grupos o movimientos religiosos ya condenados previamente reforzaba extraordinariamente los argumentos doctrinales ${ }^{112}$. No en vano, los propios arrianos utilizaron también el mismo procedimiento para agredir dialécticamente a los defensores del credo niceno. El autor del Opus Imperfectum se refiere a los católicos cuando afirma que de generatione impiorum Iudaeorum et gentilium sunt haeretici isti ${ }^{113}$. En los comentarios al Concilio de Aquileya, Paladio de Ratiaria aseguraba que el rechazo de la profesión de fe de Arrio había sido consecuencia de la cons-

\footnotetext{
111 Jerónimo, In Hier., XVII, 5-6 (ed. S. ReITER, en CCL 74, pág. 209): [...] Illud de Iudaeis dictum sit et de hereticis qui spem habent in homine, in Christo uidelicet suo, quem non filium Dei, sed purum hominem putant esse uenturum [...]. Cfr. In Matth., II, 36: 13, 55-56 (ed. bilingüe de V. Bejarano, San Jerónimo. Obras completas, II. Comentario a Mateo y otros escritos [Madrid 2002] BAC 624, pág. 182): Error iudaeorum salus nostra est et hereticorum condemnatio. In tantum enim cernebant hominem Iesum Christum ut fabri putarent filium [...]. Vid. B. Jeanjean, Saint Jérôme et l'hérésie (Paris 1999) pág. 171; R. GonZÁlez SAlinero, Biblia y polémica antijudía, págs. 127-128. De hecho, para Jerónimo la sumisión del Hijo y su crucifixión constituían un mismo escándalo: vid. B. JEANJEAN, «Una exégèse antiarienne de Grégoire de Nazianze dans la Lettre $55 \mathrm{de}$ Jérôme», en Les chrétiens face à leurs adversaires dans l'Occident latin au IV siècle, ed. J.-M. POINSOTTE (Rouen 2001) págs. 197-198.

112 R. LYMAN, «A Topography of Heresy: Mapping the Rhetorical Creation of Arianism», en Arianism after Arius. Essays on the Development of the Fourth Century Trinitarian Conflicts, eds. M. R. BARNES y D. H. WILliams (Edinburgh 1993) págs. 48 y $55-57$.

${ }^{113}$ Op. Imp., col. 894.
} 
piración tramada por los católicos a imitación de los judíos, por lo que terminarían por caer en su propia perdición ${ }^{114}$. Al modo de ver de los arrianos, sólo existía una Iglesia de Dios, columna et firmamentum ueritatis, y un solo pueblo, pues el resto de los que se hacían llamar cristianos (principalmente los católicos) no se reunían en iglesias de Dios, sino en «sinagogas de Satanás» ${ }^{115}$. Según las Constituciones Apostólicas, los herejes católicos se conducían como los judíos perseguidores y se dejaban contagiar de su ignorancia ${ }^{116}$. Y el obispo arriano Maximino les acusó de poseer un dicurso verbal falseado y de haber caído en la abominación de los judíos al renegar del Señor ${ }^{117}$.

\section{LA POLÉMICA ANTIJUDÍA EN LA LITERATURA ARRIANA}

Probablemente no haya mejor prueba para desmentir el mito del filojudaísmo arriano que la constatación de la inequívoca presencia de la polémica antijudía en la literatura arriana. Formando parte de

\footnotetext{
${ }^{114}$ Scolia in Concilium Aquileiense, frag. 75 (ed. R. GRYSON, Scolies ariennes sur le Concile d'Aquilée [Paris 1980] SC 267, pág. 184). Cfr. frag. 112 (R. GRYSON, pág. 298); Contra hereticos (Collectio Veronensis), 5 (ed. R. GRYSON, en CCL 87, pág. 145); II homilía anónima, 11 (ed. J. LIÉBAERT, Deux homélies anoméennes pour l'Octave de Paques [Paris 1969] SC 146, pág. 106) y 26 (Ibid., pág. 124).

${ }^{115}$ Scolia in Concilium Aquileiense, frag. 33 (R. GRYSON, Scolies ariennes, pág. 163). Cfr. Epistula de fide, uita et obitu Ulfilae, 33 [53] (CCL 87, pág. 163).

${ }^{116}$ Const. Apost., II, 21, 2 (M. METZGER, Les Constitutions, I, págs. 204-206 = F. X. FunK, Didascalia et Constitutiones, I, pág. 79); V, 16, 2 (M. METZGER, Les Constitutions, II, pág. 262 = F. X. FUnK, Didascalia et Constitutiones I, pág. 283); VI, 5, 1 (M. Metzger, Les Constitutions, II, pág. 302 = F. X. FunK, Didascalia et Constitutiones, I, pág. 309); VIII, 2, 4 (M. METZGER, Les Constitutions, III, pág. 136 = F. X. Funk, Didascalia et Constitutiones, I, pág. 468). Cfr. Op. Imp. (PG 56, cols. 888-889). Vid. R. P. VAGgione, «Of Monk and Lounge Lizards: "Arians", Polemics and Ascetism in the Roman East», en Arianism after Arius. Essays on the Development of the Fourth Century Trinitarian Conflicts, eds. M. R. BARNES y D. H. WiLliams (Edinburgh 1993) pág. 198.

${ }^{117}$ Scolia in Concilium Aquileiense, frag. 36 (R. GRYSON, Scolies ariennes, pág. 232).
} 
la Collectio Veronensis ha llegado hasta nosotros un valioso escrito de Maximino bajo el significativo título de Contra Iudaeos qui sunt secundum litteram Iudei non secundum spiritum ${ }^{118}$, obra redactada hacia el 428 en África, provincia a la que el autor había viajado en compañía del comes Sigisvulto con el fin de propagar el credo arriano ${ }^{119}$. Aunque D. B. Capelle consideraba que este tratado tenía un valor estilístico menor que sus sermones, los argumentos de la polémica aparecen presentados con gran habilidad ${ }^{120}$. Sin embargo, no sería ésta la única obra Adversus Iudaeos redactada por mano arriana ${ }^{121}$. Gracias a Jerónimo, sabemos que Eusebio de Emesa, un obispo semiarriano del siglo IV, escribió, entre otras obras, un

${ }^{118}$ C. H. TURNER, «St. Maximus of Turin Contra Iudaeos, with a Description of the Verona MS (II [49])», Journal of Theological Studies 20 (1919) págs. 289-310 (aunque erróneamente adjudicado a Máximo de Turín, esta edición del texto, en págs. 293-310, es muy superior a la recogida como tractatus V en $P L 57$, cols. 794-806). La última y mejor edición corresponde a R. GRYSON, en CCL 87, págs. 93-117.

${ }^{119}$ Vid. F. FERRÈre, La situation religieuse de l'Afrique romaine depuis la fin di $I V^{e}$ siècle jusqu'a l'invasion des Vandales (429) (Paris 1897; reimpr. Amsterdam 1970) pág. 351. Algunas de sus citas escriturarias toman como base el texto proveniente de una de las versiones de la Vetus Latina africana: R. GRYSON, «Les citations scripturires des oeuvres attribuées à l'évêque arien Maximinus», Revue Bénédictine 88 (1978) pág. 78. En cuanto a la datación de la obra, una reminiscencia de la discusión con Agustín permite situarla poco después del 428: B. Blumenkranz, Les auteurs chrétiens latins du moyen âge sur les juifs et le judaïsme (Paris - La Haye 1963) págs. 17-18. Sobre este tratado en general, vid. A. LUKYn Williams, Adversus Judaeos. A Bird's-Eye View of Christian Apologiae until the Renaissance (Cambridge 1935) págs. 306 ss.; M. MESLin, Les ariens, págs. 365 ss.; H. SCHRECKENBERG, Die christlichen Adversus-Judaeos-Texte, págs. 331 ss.; S. KRAuSS y W. HORBuRY, The Jewish-Christian Controversy from the Earliest Times to 1789, I. History (Tübingen 1995) pág. 41.

${ }^{120}$ D. B. CAPELLE, «Un homéliaire de l'évêque arien Maximin», Revue Bénédictine 34 (1922) págs. 88-89. Sobre las fuentes de Maximino, vid. J. H. BAXTER, «St. Maximus Contra Iudaeos: Parallels in Earlier Writers», Journal of Theological Studies 21 (1920) págs. 175-177; A. LUKYN WiLliams, Adversus Judaeos, pág. 311, n. 1; M. MESLIN, Les ariens, págs. 366-367.

${ }^{121}$ B. BLUMENKRANZ (Les auteurs, pág. 18) se equivocó al afirmar que este tratado contra los judíos de Maximino constituía una rara excepción: «Ce texte présente cet intérêt particular qu'il est une des rares polémiques des Ariens contre les Juifs, qui tous deux furent, la plupart du temps, des alliés naturels». 
tratado titulado Contra los judios, gentiles y novacianos ${ }^{122}$. Contamos, además, con el Comentario a Job del arriano Juliano ${ }^{123}$ y con las homilías de Asterio el Sofista, autor arriano del siglo IV de probable origen judío que vivió en Palestina o Siria y que, al igual que el católico Juan Crisóstomo, combatió con energía la influencia de la religión judía sobre muchos cristianos de su tiempo ${ }^{124}$. Ahora bien, teniendo en cuenta la importancia que en ella adquiere el ataque al judaísmo, no tendría menos valor la obra titulada Opus imperfectum in Matthaeum, cuyo autor parece haber sido un obispo de una pequeña comunidad arriana que ve cómo sus miembros decrecen diariamente en número ante el empuje de los católicos ${ }^{125}$.

\footnotetext{
122 Jerónimo, Chron. (GCS 7, 1, pág. 236). Vid. J. QUASTEN, Patrología, II. La edad de oro de la literatura patrística griega (Brussels 1960; Madrid, 19945) pág. 389.

${ }^{123}$ Vid. D. HAGEDORN, Der Hiobkommentar des arianers Julian (Berlin - New York 1973) págs. LIII-LVI, para quien se trataba de un autor que escribió a partir de las décadas del 350 ó 360 y que mantuvo una estrecha relación con Antioquía.

${ }^{124}$ Vid. H. SCHRECKENBERG, Die christlichen Adversus-Judaeos-Texte, pág. 271; W. KInZIG, Erbin Kirche. Die Auslegung von Psalm 5,1 in den Psalmenhomilien des Asterius und in der Alten Kirche (Heildelberg 1990) págs. 104-107.

${ }^{125}$ Vid. F. KAUfFMANN, Zur Textgeschichte de "Opus imperfectum in Matthaeum» (Kiel 1909); G. MORIN, «Quelques aperçus nouveaux sur l'Opus imperfectum in Matthaeum», Revue Bénédictine 37 (1925) págs. 239-262; M. SimONETTI, «Note sull'Opus imperfectum in Matthaeum», Studi Medievali 10 (1969) págs. 120 ss.; J. P. BOUHOT, «Remarque sur l'histoire du texte de l'Opus imperfectum in Matthaeum», Vigiliae Christianae 24 (1970) págs. 197-209; M. MESLIn, Les ariens, págs. 135-149 y 221-226; M. SimonetTI, en Patrología, III. La edad de oro de la literatura patrística latina, dir. A. DI BERARDINO (Roma - Torino 1978; Madrid 1993) págs. 117-119. Sobre las diferentes hipótesis sobre su autoría, vid. C. MAGAZZÙ, «Motivi encratiti nell'Opus imperfectum in Matthaeum», en 'A $\alpha \alpha \theta \dot{\eta}$

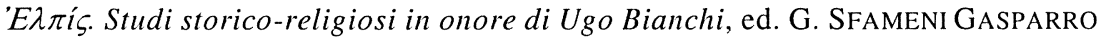
(Roma 1994) pág. 429 (M. MESLIN, Les ariens, pág. 179, pensaba que se trataba del propio Maximino). Para M. WILES (Archetypal Heresy, pág. 38) sería una obra procedente de Siria y redactada a principios del siglo V; J. H. A. VAN BANNING se limita a indicar que su redacción ha de situarse con seguridad entre el año 400 y el 450: J. H. A. VAN BANNING, «The Edition of the Arian Opus Imperfectum in Matthaeum. Review and Prospects», en Studia Patristica, XX, ed. E. A. LivingSTONE (Leuven 1989) pág. 71. Según F. MALI (Das 'Opus imperfectum in Matthaeum' und sein Verhältnis zu den Matthäuskommentaren von Origenes und Hieronymus [Innsbruck 1991] págs. 333-339), el autor de esta obra hizo amplio
} 
Igualmente, los textos de carácter canónico o pseudo-canónico, como algunos anatemas del Concilio de Sirmio (351/352) ${ }^{126}$ y las Constituciones Apostólicas ${ }^{127}$, reflejan un evidente rechazo hacia los judíos. Por último, diversas homilías, tractatus y commentarii anónimos, junto con algunos fragmentos conservados de obras arrianas desaparecidas, destilan por doquier ideas antijudías ${ }^{128}$.

En realidad, apenas encontramos diferencias significativas entre la teología antijudía católica y la arriana. Los seguidores de la doctrina de Arrio también consideraban que los judíos habían sido siempre malvados, criminales y perseguidores de Cristo y de los cristianos ${ }^{129}$. El autor del Opus Imperfectum trató de explicar a sus fieles que los hijos de Caín, el perseguidor y asesino de Abel, no

uso de las fuentes en lengua griega, especialmente del Comentario a Mateo de Orígenes.

${ }^{126}$ La fórmula de Sirmio (primero del 351 y después del 357 ) nos ha llegado gracias a las citas de Atanasio, Hilario de Poitiers, Sócrates y Sozomeno: E. J. JONKERS, Acta et Symbola Consiliorum quae saeculo quarto habita sunt (Leiden 1954) págs. 102-104. Sobre el particular, vid. H. M. GWATKIN, Studies of Arianism, págs. 157 ss.; CH. J. HefEle, A History of the Canons, págs. 194 ss. Respecto a la controversia de la atribución de la fórmula de Sirmio del 357 a Potamio de Lisboa, vid. A. MonTes Moreira, Potamius de Lisbonne et la controverse arienne (Louvain 1969) págs. 113-159 (este autor llega a la conclusión de que no existen pruebas seguras de que Potamio fuese el autor de dicha fórmula: págs. 311-312). Sobre los anatemas antijudíos, vid. especialmente $\mathrm{H}$. SCHRECKENBERG, Die christlichen Adversus-Judaeos-Texte, pág. 275.

${ }^{127}$ Obra compilada por mano arriana en Siria (quizás en Antioquía) hacia finales del siglo IV o principios del V, que comprende material litúrgico, teológico y jurídico. Contiene además un apéndice (el libro octavo) con 85 cánones conocidos como «Cánones Apostólicos». Vid. A. M. RABEllo, Giustiniano, Ebrei e Samaritani, II, pág. 530 .

${ }^{128}$ Sobre todos estos escritos destaca, sin duda, el Commentarius in Job de Pseudo-Orígenes, obra latina del siglo VI cuyo autor parece haber pertenecido a la elite arriana del norte de África. Su contenido denota la existencia de una especial preocupación ante la pérdida de fuerza de los vándalos arrianos por el avance de la creencia nicena. Sobre el particular, vid. L. DosSEY, «The Last Days of Vandal Africa: An Arian Commentary on Job and Its Historical Context», Journal of Theological Studies 54 (2003) especialmente págs. 61-65, 83 ss. y 111 ss.

${ }^{129}$ Anonymus in Iob (PL 17, col. 408); Scolia in Concilium Aquileiense, frag. 75 (R. GRYSON, Scolies ariennes, pág. 185). 
eran otros que los propios judíos, cuyo único destino estaba consagrado a la iniquidad y a los crímenes ${ }^{130}$. Su irrefrenable maldad les había empujado a acabar ignominiosamente con la vida de Cristo ${ }^{131}$ y, aun después del deicidio, a perseguir y asesinar a Esteban, así como a colaborar activamente en la muerte del Bautista ${ }^{132}$. La dureza de corazón de los judíos sólo era superada por la frialdad de su espíritu y la maléfica implacabilidad de su alma ${ }^{133}$. En este sentido, Maximino refuerza la antítesis entre judíos y cristianos utilizando diferentes recursos retóricos de claro acento paulino ${ }^{134}$ :

\footnotetext{
${ }^{130}$ Op. Imp., col. 894: [...] Omnium iniquorum et persequutorum et homicidarum a Cain usque ad finem [...] Postmodum conversae sunt gentes quaedam ad Christum, surrexerunt perfidi Iudaei post Christum adversus Christianos, ipsa vice habentes ipsam generationem quantum animam, quam habuerunt gentes illae, quae prius persequebantur, Iudaei autem defecerunt, qui persequebantur Ecclesiam [...]. Cfr. Tract. in Luc. evang., V, 14 (PLS, I, col. 341).

${ }^{131} \mathrm{Al}$ igual que sucedía en la literatura ortodoxa, el tema del deicidio constituía la principal acusación contra los judíos en las fuentes arrianas: Maximino, Contr. Iud., VIII, 3 (CCL 87, pág. $106=$ VI, 23-25: C. H. TURNER, «St. Maximus of Turin Contra Iudaeos», pág. 302): Occidistis d(omi)n(u)m, et gratulamini. Occidistis quidem, sed non occidistis tamen; occidistis uoluntate, sed non occidistis in ueritate, quia Chr(istu)s in aeternum manet [...]. Cfr. Op. Imp., cols. 636 ss., 863864, 983 ss., y especialmente la homilia III (in sancta Pascha); Collectio Veronensis: Contra Iudaeos, VIII, 1-3 (CCL 87, págs. 105-106); Asterio el Sofista, Comm. psalm., V, 22 (M. RICHARD, Asterii Sophistae, págs. 42-42); Scolia in Concilium Aquileiense, frag. 45 (R. GRYSON, Scolies ariennes, pág. 168); frag. 70, de Maximino (R. GRYSON, Scolies ariennes, pág. 256); Collectio Veronensis: De sollemnitatibus, III, 1 (CCL 87, pág. 56); X, 4 (CCL 87, pág. 76); Fragmenta in Lucam rescripta, frag. 5, 14 (CCL 87, pág. 220). Para Asterio, no habría duda de

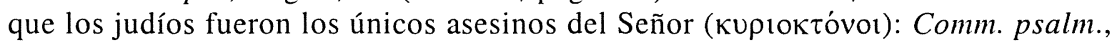
VIII, 9 (M. RICHARD, Asterii Sophistae, pág. 67); XI, 1 (Ibid. pág. 75); XXXI, 4 (Ibid., págs. 243-244). Vid. H. SCHRECKENBERG, Die christlichen AdversusJudaeos-Texte, págs. 270-271.

${ }^{132}$ Op. Imp., homiliae IX (in natale sei Iohannis) y X (in natale sancti Stephani). Vid. M. MESLIN, Les ariens, pág. 375.

${ }^{133}$ Op. Imp., col. 776. Vid. M. MESLin, Les ariens, págs. 375-376.

${ }^{134}$ De hecho, al contrario de lo que cabría suponer a tenor de las acusaciones lanzadas por los ortodoxos, los arrianos pusieron mayor énfasis en el Nuevo Testamento que en el Antiguo, acudiendo con una mayor profusión a citas neotestamentarias para reforzar sus argumentaciones. Sobre el particular, vid. M. WILES, Archetypal Heresy, págs. 14-17.
} 
Ahora ya se distingue lo que ha sido cumplido en el Santo Evangelio de aquello que entonces había sido escrito en la Ley, cuando decíais en aclamación: «[caiga] su sangre sobre nosotros y sobre nuestros hijos» [Mt. 27, 25]; para nosotros, en cambio, esta frase equivale a decir salvíficamente: «su sangre sobre nosotros y sobre nuestros hijos»; para vosotros supone la condenación, para nosotros la salvación, pues, en un sentido diferente al vuestro, nosotros pronunciamos esta frase con discernimiento; mientras vosotros os enfurecéis, nosotros rezamos; mientras vosotros insultáis, nosotros rogamos humildemente; mientras que en vosotros dicha frase nace del odio, en nosotros surge del amor; mientras que vosotros os entristecéis, nosotros nos regocijamos. Vosotros elegisteis al ladrón, porque todo animal busca siempre a su semejante; nosotros elegimos al Señor, aunque más bien fue el Señor quien nos eligió a nosotros, porque somos del Señor $[\ldots]^{135}$.

En la misma línea que este texto de Maximino se pronunció el autor del Commentarius in Iob cuando afirmaba que la resurrección de Cristo había supuesto la luz del Espíritu Santo para los cristianos y, en cambio, la oscuridad para los judíos (tenebrosus populus) ${ }^{136}$. Según Asterio, al preferir éstos a Barrabás antes que a Cristo, y el reino de César al de los Cielos, renunciaron voluntariamente a toda fuente de vida ${ }^{137}$. Guiados por la letra carnal y ciegos a todas las evidencias enunciadas alegó-

\footnotetext{
${ }^{135}$ Maximino, Contr. Iud., VIII, 1-2 (CCL 87, pág. 105 = VI, 7-16: C. H. TuRNER, «St. Maximus of Turin Contra Iudaeos», págs. 301-302): [...] De quo iam tunc in lege fuerat scribtum quod in sancto aeuangelio completum esse dinoscitur, quando clamabatis dicentes: Sanguis eius super nos et super filios nostros. Sed nobis haec salubriter conpetit dicere: Sanguis eius super nos et super filios nostros, uobis ad condemnationem, nobis uero ad salutem, quia alio uos proposito, alio nos dicimus intellectu, uos furendo, nos orando, uos insultando, nos suppliciter postulando, uos ex odio nos ex amore, uos ut tristes, nos autem ut semper gaudentes. Vos latronem elegistis, quia omnis animal ad sibi simile conuertitur; nos dominum elegimus, immo magis dominus nos elegit, quia domini sumus [...]. Sobre la utilización por parte de Maximino de Mt 27, 25 como una especie de maldición para los judíos, vid. R. KAMPLING, Das Blut Christi und die Juden. Mt 27,25 bei den lateinischsprachigen christlichen Autoren bis zu Leo dem Großen (Münster 1984) pág. 115.

${ }^{136}$ Comm. in Iob, PL 17, cols. 519-520.

${ }^{137}$ Asterio el Sofista, Comm. psalm., V, 22 (M. RICHARD, Asterii Sophistae, págs. 42-43). Vid. H. SCHRECKENBERG, Die christlichen Adversus-Judaeos-Texte, pág. 270.
} 
ricamente en el Antiguo Testamento, rechazaron al Salvador y, por tanto, se vieron alejados para siempre del Reino Celestial ${ }^{138}$. La incredulidad de los judíos era su condena ${ }^{139}$, ya que, como afirma Maximino, representaba su «cárcel eterna» ${ }^{140}$.

Hasta ahora hemos observado que el pensamiento cristológico de los arrianos no se distanciaba mucho del ortodoxo. De alguna forma, la anulación de la incredulidad judaica así lo exigiría. En este sentido, M. Meslin apreció acertadamente que Maximino desarrolló argumentos ambivalentes que eran susceptibles de una doble lectura: de carácter ortodoxo contra los judíos, y «herético» contra la teología trinitaria. Tras enumerar las diversas teofanías del Antiguo Testamento, el obispo arriano trató de demostrar a los judíos que el

${ }^{138}$ Op. Imp., cols. 806-810; Tract. in Luc. evang., 53 (ed. A. HAMMAN, en PLS, I, col. 333); Asterio, Comm. psalm., XVIII, 15 (M. RiCHARD, Asterii Sophistae, págs. 132-135); Const. Apost., VII, 36, 2 (M. METZGER, Les Constitutions, III, pág. $82=$ F. X. FunK, Didascalia et Constitutiones, I, págs. 434-435); VIII, 15, 7 (M. Metzger, Les Constitutions, III, pág. $214=\mathrm{F}$. X. Funk, Didascalia et Constitutiones, I, págs. 520-521). Maximino recurre a numerosos textos veterotestamentarios susceptibles de interpretación cristológica: Contr. Iud., capítulos I-IV (CCL 87, págs. 93-100 = I-III: C. H. TURNER, «St. Maximus of Turin Contra Iudaeos», págs. 293-297). Vid. en general, B. Blumenkranz, Les auteurs, págs. 18-19; M. Meslin, Les ariens, págs. 369, 371 y 376. Para el autor del Opus Imperfectum, el rechazo de Cristo por parte de los judíos obedecía a su obsesión por seguir la letra de las Escrituras y a su alejamiento de la interpretatio spiritualis (Op. Imp., cols. 726, 808-810, etc.). Vid. F. W. SCHLATTER, «The Opus Imperfectum in Matthaeum and the Fragmenta in Lucam», Vigiliae Christianae 39 (1985) pág. 386.

${ }^{139}$ Vid. Maximino, Contr. Iud., VII, 7 (CCL 87, pág. $105=$ V, 49-52: C. H. TURNER, «St. Maximus of Turin Contra Iudaeos», pág. 301); Op. Imp., col. 646; Scolia in Concilium Aquileiense, 21 (R. GRYSON, Scolies ariennes, pág. 159); Fragmenta in Lucam rescripta, 1, 53 (CCL 87, pág. 208); Const. Apost., II, 60, 2 (M. Metzger, Les Constitutions, I, págs. 326-328 = F. X. FunK, Didascalia et Constitutiones, I, pág. 172-173).

${ }^{140}$ Maximino, Contr. Iud., IX, 7 (CCL 87, págs. 108-109 = VII, 56-57: C. H. TURNER, «St. Maximus of Turin Contra Iudaeos», pág. 304): [...] Sed etsi sunt aliqui reges aut gentes aliquae quae nolunt adorare, sicuti et uos Iudaei, manet carcer aeternus, manet iudicium Dei [...]. Vid. M. MesLin, Les ariens, pág. 369. El autor anónimo del Opus Imperfectum (col. 893) aseguraba que al final de los tiempos la ira de Dios caería sobre los judíos por la crucifixión de Cristo y la persecución de sus discípulos (vid. M. MESLin, Les ariens, pág. 376). 
Hijo estuvo presente, desde el origen, al lado del Padre y que se manifestó a los hombres por medio de su Encarnación ${ }^{141}$. Ahora bien, aunque para probar a los judíos la existencia del Hijo, glosa el Salmo 2, 7 (filius meus es tu, ego hodie genuit te), no puede negarse que, en oposición al credo de Nicea, desarrolla al mismo tiempo la tesis de la generación del Hijo por el Padre, oponiendo Ingenitus (el Padre) a Unigenitus (el Hijo), según la más pura tradición arriana ${ }^{142}$. Tal y como manifiesta Maximino, el Padre (Genitor) era diferente al Hijo (Adiutor) ${ }^{143}$ y el Espíritu Santo posterior a la generación del Hijo. De este modo, el obispo arriano introducía en el misterio de la Trinidad una doble temporalidad que jerarquizaba a las Personas. Implicaba, en definitiva, la sumisión del Hijo al Padre ${ }^{144}$. De hecho, engendrado el primero de todas las criaturas, agente subordinado a la voluntad del Padre, el Hijo no era más que Señor: «así pues, nosotros, los verdaderos cristianos, confesamos y creemos (tal y como dijimos) en un solo Dios, el Padre, y en un solo Señor, nuestro Jesucristo, su Hijo» ${ }^{145}$, quien actuaría, en realidad, como el intermediario entre Dios y los hombres ${ }^{146}$. Nada de esto, sin embargo, impidió a Maximino rebatir la incredulidad judaica respecto a la divinidad (si bien subordinada) de Cristo,

${ }^{141}$ Sobre el particular, vid. A. LUKYN WILliams, Adversus Judaeos, pág. 308.

${ }^{142}$ Contr. Iud., III, 2 (CCL 87, pág. 97 = II, 47-48: C. H. TURNER, «St. Maximus of Turin Contra Iudaeos», pág. 295): [...] Vnus unum genuit, solus solum, deus deum, rex regem, ingenitus unigenitum, pater filium, auctor uerbum [...].

${ }^{143}$ Contr. Iud., XIV, 6 (CCL 87, págs. 116-117 = XI, 39-40: C. H. TURnER, «St. Maximus of Turin Contra Iudaeos», pág. 310).

${ }^{144}$ Contr. Iud., II, 4 (CCL 87, pág. 96 = II, 28: C. H. TURNER, «St. Maximus of Turin Contra Iudaeos», pág. 295): [...] Pater imperauit et Filius adimpleuit [...]; II, 5 (CCL 87, pág. 96 = II, 33: C. H. TuRnER, «St. Maximus of Turin Contra Iudaeos», pág. 295): [...] ex cuius iussione [Patris], pluit filius [...]; XII, 2 (CCL 87, pág. 112 = IX, 33-34: C. H. TURNER, «St. Maximus of Turin Contra Iudaeos», pág. 307): [...] In ipso fecit qui quod iussum est adinpleuit [...]

${ }^{145}$ Contr. Iud., XV, 1 (CCL 87, pág. 117 = XI, 43-44: C. H. TURner, «St. Maximus of Turin Contra Iudaeos», pág. 310): Nos ergo cristiani unum, ut diximus, deum patrem credimus et confitemur, et unum dominum nostrum lesum Christum filium eius [...].

${ }^{146}$ Vid. M. MESLin, Les ariens, págs. 373-374. 
argumento central en el que, a su vez, fundamentaba Asterio todo su pensamiento antijudío ${ }^{147}$. En realidad, el subordinacionismo de los arrianos no les predispuso a la comprensión de los judíos, demasiado sujetos a un monoteísmo estricto, tal y como les habían reprochado sus más férreos adversarios católicos ${ }^{148}$.

El castigo divino que había recaído sobre los judíos a causa del deicidio, su incredulidad y sus innumerables pecados, se había manifestado en la destrucción de Jerusalén a manos de los romanos $y$, una vez desterrados de su tierra natal, en su infausto deambular por el Imperio en una perpetua Diáspora ${ }^{149}$. Con todo, Asterio advierte que gozaron de un tiempo limitado para su arrepentimiento (desde la muerte de Cristo en el Gólgota hasta el 70 d. C.) que, desgraciadamente para ellos, no aprovecharon ${ }^{150}$. En consecuencia, la Iglesia ocupó su lugar por medio de una nueva Alianza, pues la

${ }^{147}$ Asterio el Sofista, Comm. psalm., XXV, 14 (M. RICHARD, Asterii Sophistae, pág. 193); XXIX, 24 (Ibid., pág. 239). Vid. M. F. WILES y R. C. GrEGG, «Asterius: A New Chapter in the History of Arianism», en Arianism. Historical and Theological Reassessments, ed. R. C. GREGG (Philadelphia 1985) pág. 126. Cfr. además Fragmenta Theologica (Bobbio), 18 (CCL 87, pág. 258); Comm. in Iob, PL 17, col. 432 .

${ }^{148}$ M. MEsLin, Les ariens, pág. 376.

${ }^{149}$ Asterio, Comm. psalm., VI, 9 (M. RiCHARD, Asterii Sophistae, pág. 49). Vid. W. KinZig, Erbin Kirche, pág. 35. Cfr. Juliano Arriano, Comm. in Iob, 125 (D. HAGEDORN, Der Hiobkommentar, pág. 259); Const. Apost., V, 14, 20 (M. Metzger, Les Constitutions, II, pág. 258 = F. X. FunK, Didascalia et Constitutiones, I, págs. 278-281); V, 20, 19 (M. METZGER, Les Constitutions, II, pág. 284 = F. X. FunK, Didascalia et Constitutiones, I, págs. 300-301); VII, 23, 4 (M. Metzger, Les Constitutions, III, pág. $50=$ F. X. FunK, Didascalia et Constitutiones, I, págs. 408-409); VIII, 47, 64 (M. METZGER, Les Constitutions, III, pág. 298 = F. X. FUnK, Didascalia et Constitutiones, I, págs. 582-585); Op. Imp., cols. 900-904. Tanto en el Opus Imperfectum (cols 861-862) como en los Fragmenta in Lucam rescripta, obras que se debieron, según F. W. SCHLATTER ( Imperfectum in Matthaeum», pág. 389), a una misma pluma, los invitados que se negaron a asistir al banquete descrito en la parábola de $M t$ 22, 1-6 representaban a los judíos, y su exterminio por parte de las tropas del rey colérico (Mt 22, 7-8) estaría haciendo referencia a la destrucción de Jerusalén a manos del ejército romano: vid. F. W. SCHLATTER, «The Opus Imperfectum in Matthaeum», págs. 387-388.

${ }^{150}$ Asterio, Comm. psalm., II, 22 (M. RiChard, Asterii Sophistae, pág. 13). Vid. H. SChreCKEnBERG, Die christlichen Adversus-Judaeos-Texte, pág. 271. 
antigua había sido definitivamente derogada. La herencia de las promesas divinas pasaría a manos de la nueva Israel, ex gentibus congregata ${ }^{151}$. El Antiguo Testamento proporcionaba, de nuevo, textos que servían como prefiguración de la futura antítesis entre la Ecclesia y la Synagoga. Siguiendo una larga tradición antijudía, Maximino enfrenta por oposición a cristianos (el verdadero pueblo de Dios) y judíos (el pueblo desheredado) por medio de la tipología bíblica ${ }^{152}$ : mientras que Caín constituía el «tipo» del pueblo judío, Abel representaba a los cristianos ${ }^{153}$; el mismo caso se daba respecto a Ismael e Isaac ${ }^{154}$, Agar y Sara ${ }^{155}$, Esaú y Jacob ${ }^{156}$, y Lía y Raquel ${ }^{157}$. Asterio pregunta retóricamente al pueblo judío si acaso su herencia no ha llegado ya a su fin, si no ha perdido su Templo y se encuentra disperso por todo el mundo bajo la autoridad de los

\footnotetext{
${ }^{151}$ Maximino, Contr. Iud., I, 1 (CCL 87, pág. 93 = I, 3-5: C. H. TURNER, «St. Maximus of Turin Contra Iudaeos», pág. 293): [...] Et primo illud mihi ostendendum uidetur quod hic populus a mundi initio diuina prouidentia reprobatur, et sequens populus eligitur adque adsumitur ex gentibus, id est populus christianus [...]; Cfr. Collectio Veronensis: De lectionibus sanctorum Evangeliorum, 20, 2 (CCL 87, pág. 37); Op. Imp., cols. 807, 813, 816, 851, passim; Tract. in Luc. evang., V, 2 (PLS, I, cols. 337-338); Asterio el Sofista, Comm. psalm., VI, 6-7 (M. RICHARD, Asterii Sophistae, pág. 47); VII, 5-6 (Ibid., pág. 56); VIII, 1-5 (Ibid., págs. 63-65); XV, 1 (Ibid., pág. 108). Respecto a este último, vid. M. Kinzig, Erbin Kirche, págs. 34, 36 y 60.

${ }^{152}$ Vid. A. LUKYN Williams, Adversus Judaeos, págs. 307-308; B. BlumENKRANZ, Les auteurs, pág. 18; M. MESLIn, Les ariens, pág. 369; H. SCHRECKENBERG, Die christlichen Adversus-Judaeos-Texte, pág. 332.

${ }^{153}$ Maximino, Contr. Iud., I, 2 (CCL 87, pág. 93 = I, 8-10 (C. H. TURNER, «St. Maximus of Turin Contra Iudaeos», pág. 293): Adam genuit Cain et Abel. Cain maior natu populum designabat iudeorum. Iste repellitur ob facinus suum, et Abel minor natu adsumitur, qui populum christianum ostendebat [...].

${ }^{154}$ Contr. Iud., VII, 1-2 (CCL 87, pág. $103=$ V, 4-15: C. H. TURNER, «St. Maximus of Turin Contra Iudaeos», págs. 299-300).

${ }^{155}$ Contr. Iud., I, 5 (CCL 87, pág. 94 = I, 24-28: C. H. TURNER, «St. Maximus of Turin Contra Iudaeos», pág. 293).

${ }^{156}$ Contr. Iud., I, 6-7 (CCL 87, pág. 94 = I, 28-36: C. H. TURnER, «St. Maximus of Turin Contra Iudaeos», págs. 293-294).

${ }^{157}$ Contr. Iud., VII, 5 (CCL 87, pág. $104=$ V, 27-35: C. H. TURNER, «St. Maximus of Turin Contra Iudaeos», pág. 300).
} 
romanos. La única «herencia» que los judíos han conseguido es, según el Sofista, una tierra ajena que nunca les perteneció.

Así pues, mientras la miserable hija de Babilonia había perdido toda su herencia, la Iglesia se había convertido definitivamente en la verdadera hija de Dios ${ }^{158}$. Prueba de ello, según Maximino, era que el pueblo cristiano había florecido y se había extendido por toda la tierra hasta llegar al borde de los océanos ${ }^{159}$. Si la Sinagoga aún persistía no era porque hubiese logrado conservar algún resto de la gracia divina, sino porque debía cumplir el castigo de guardar y transmitir a generaciones posteriores (como si se tratara de un archivero) las Sagradas Escrituras que había recibido en depósito (que no en herencia), prestando así testimonio vivo de la verdad del cristianismo ${ }^{160}$.

Puesto que la Antigua Alianza había sido sustituida por una Nueva ante la llegada de Cristo y el surgimiento de la Iglesia como Verus Israel, la Ley mosaica quedaba, en consecuencia, derogada ${ }^{161}$. Ninguna de sus prácticas religiosas encontraba ya justifica

${ }^{158}$ Asterio el Sofista, Comm. psalm., VI, 9 (M. RICHARD, Asterii Sophistae, págs.

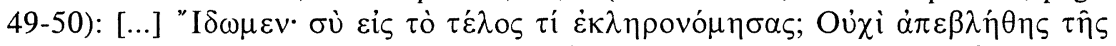

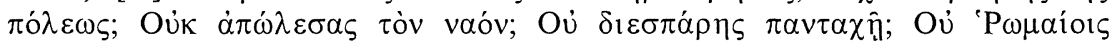

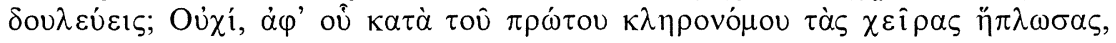

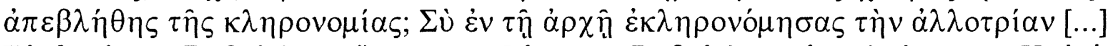

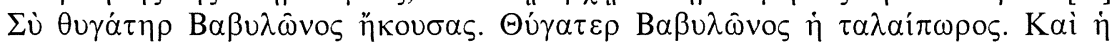

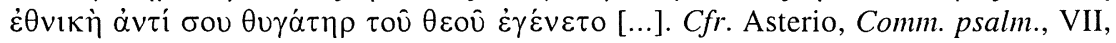
5-6 (M. RICHARD, Asterii Sophistae, págs. 56-57); XI, 10 (Ibid., pág. 80); XV, 1 (Ibid., pág. 108). Vid. W. KinZIG, Erbin Kirche, pág. 38. En Asterio estuvo también presente la imagen de la Sinagoga como adúltera frente a la Iglesia como esposa fiel de Cristo: Comm. psalm., VIII, 4 (M. RICHARD, Asterii Sophistae, pág. 64).

${ }^{159}$ Contr. Iud., IX, 3-5 (CCL 87, págs. 107-108 = VII, 18-37: C. H. TURNER, «St. Maximus of Turin Contra Iudaeos», pág. 303). Cfr. Tract. in Luc. evang., V, 2 (PLS, I, col. 337). Vid. A. LUKyn Williams, Adversus Judaeos, pág. 309.

${ }^{160}$ Asterio el Sofista, Comm. psalm., VI, 7 (M. RiChard, Asterii Sophistae, pág.

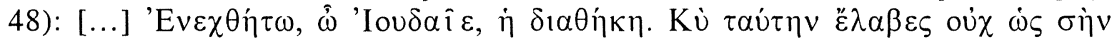

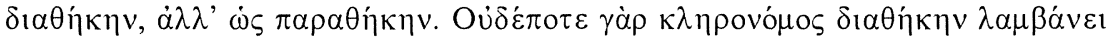

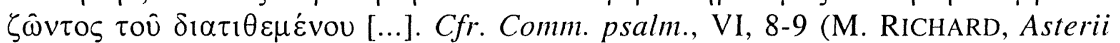
Sophistae, págs. 48-49). Vid. W. KinZIG, Erbin Kirche, pág. 35; H. SCHRECKENBERG, Die christlichen Adversus-Judaeos-Texte, pág. 271.

${ }^{161}$ Asterio, Comm. psalm., XI, 5 (M. RICHARD, Asterii Sophistae, pág. 77); Maximino, Contr. Iud., VII, 6 (CCL 87, pág. 104 = C. H. TURNER, «St. Maximus 
ción. Incluso, tal y como afirma el autor anónimo del Commentario $a \mathrm{Job}$, ni siquiera ciertas figuras del Antiguo Testamento como Job, Noé, Abrahán o Melquisedek desarrollaron su oficio sacerdotal de acuerdo a la Ley, sino conforme a la «sabiduría natural» requerida para ello ${ }^{162}$. Tampoco el establecimiento primigenio de la Ley fue firme, ya que, según opina Maximino, al destruirse las primeras Tablas entregadas a Moisés, las segundas fueron las únicas verdaderas, razón por la que «Deuteronomio» significaba 'segunda Ley' ${ }^{163}$. En cualquier caso, la Ley carnal y literal por la que finalmente llegaron a regirse los judíos sólo conducía a la muerte ${ }^{164}$. Para obtener su verdadero significado debía interpretarse de forma alegórica. Las

of Turin Contra Iudaeos», p); I homilía anónima, 7 (J. LIÉBAERT, Deux homélies anoméennes, pág. 66); Const. Apost., II, 36, 2 (M. METZger, Les Constitutions, I, pág. 260 = F. X. FunK, Didascalia et Constitutiones, I, págs. 120-123); VI, 23, 3 (M. Metzger, Les Constitutions, II, pág. 370 = F. X. Funk, Didascalia et Constitutiones, págs. 358-361). Según D. JUDANT (Judaïsme et christianisme, pág. 34), resulta especialmente evidente que el compilador de las Constituciones Apostólicas tuvo muy presente el peligro que suponía la influencia de las prácticas legales judías sobre los cristianos al tratar de resaltar la definitiva abolición de las prescripciones de la Ley. De hecho, en ellas se prohíbe a los cristianos, ya sean laicos o clérigos, toda clase de relaciones con los judíos: Const. Apost., II, 60 (M. Metzger, Les Constitutions, I, págs. $326-330=\mathrm{F}$. X. FunK, Didascalia et Constitutiones, I, págs. 172-175): vid. M. METZger, Les Constitutions, II, pág. 17; A. M. Rabello, Giustiniano, Ebrei e Samaritani, II, págs. 534-536 (respecto a los Cánones Apostólicos 70 y 71).

${ }^{162}$ Comm. in Iob, PL 17, col. 395. Vid. L. DosSEY, «The Last Days», pág. 80.

${ }^{163}$ Es muy posible que, en este sentido, el obispo arriano hubiese obtenido dicha explicación sobre Ex 34, 1-27 de algún midrás: [...] Prepárate dos tablas de piedra, como las primeras que tú rompiste y escribiré sobre ellas las palabras de las otras [...]. Teniendo en cuenta que el título hebreo de Deuteronomio era «He aquí

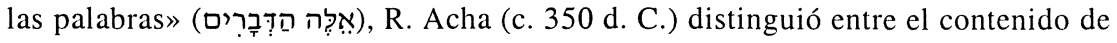
la primera y el de la segunda serie de las Tablas, siendo así que la primera recogía sólo los diez mandamientos, mientras que la segunda incluía halakot, midrasim y hagadot. El autor cristiano del Diálogo entre Timoteo y Áquila (fol. $77 \mathrm{r}^{\circ}$ ) expuso una explicación aún más amplia sobre Deuteronomio (F. C. CONYBEARE, The Dialogues of Athanasius and Zacchaeus and of Timothy and Aquila, Oxford, 1898, pág. 66). Sobre el particular, vid. A. LuKYN WiLliams, Adversus Judaeos, pág. 307, n. 1; S. Krauss y W. Horbury, The Jewish-Christian Controversy, pág. 41, n. 24.

${ }^{164}$ Op. Imp., col. 672; Comm. in Iob, PL 17, col. 502; I homilía anónima, 1 (J. LIÉBAERT, Deux homélies anoméennes, pág. 56). 
inútiles purificaciones de los judíos (como las de los paganos) de nada servirían para borrar sus numerosos pecados ${ }^{165}$, ni para frenar su carnalidad y desenfrenada concupiscencia ${ }^{166}$. Tampoco las filacterias surtirían efecto alguno, pues debían entenderse solamente desde una perspectiva espiritual ${ }^{167}$, al igual que el descanso sabático, que sólo había servido a los judíos para sucumbir ante la ociosidad y dejarse seducir por la satisfacción del cuerpo ${ }^{168}$. Ninguna salvación, en fin, proporcionaría el signo de la circuncisión, que supondría, en cambio, una marca infame (dehonestationem corporis) también para los arrianos ${ }^{169}$. Al igual que otros padres de la Iglesia, Maximino afirmaba que Abrahán (como tantos otros hombres santos del Antiguo Testamento) no se justificaba por la circuncisión carnal, sino por la fe, verdadera circuncisión del corazón (circumcisio uero

${ }^{165}$ Const. Apost., II, 35, 1 (M. MEtzger, Les Constitutions, I, págs. 256-257 = F. X. Funk, Didascalia et Constitutiones, págs. 118-121); VI, 23, 5 (M. METZGER, Les Constitutions, II, págs. 370-373 = F. X. FUnK, Didascalia et Constitutiones, págs. 358-361).

${ }^{166}$ Op. Imp., col. 799. Vid. C. MAgazzù, «Motivi encratiti», págs. 433-434. Para Maximino, al igual que sucede con las serpientes que se arrastran por el polvo, los judíos obececen sólo a la carne, sin reparar en la interpretación espiritual de las Escrituras: Contr. Iud., IX, 5 (CCL 87, pág. 108 = VII, 32-37: C. H. TURNER, «St. Maximus of Turin Contra Iudaeos», pág. 303). Vid. H. SCHRECKENBERG, Die christlichen Adversus-Judaeos-Texte, pág. 332.

${ }^{167}$ Sermo de virginitate, II, 41 (ed. D. AMAD y M. CH. Moons, «Une curieuse homélie grecque inédite sur la virginité adressée auc pères de famille», Revue Bénédictine 63 (1953) pág. 43).

${ }^{168}$ Tract. in Luc. evang., VI, 2 (PLS, I, col. 343). Las Constituciones Apostólicas se pronuncian contundentemente contra el sábado, pues había sido sustituido ya definitivamente por el domingo, día de la resurrección del Señor: V, 14, 20 (M. Metzger, Les Constitutions, II, pág. 258 = F. X. FunK, Didascalia et Constitutiones, I, págs. 278-281); VII, 23, 3 (M. METZger, Les Constitutions, III, pág. $50=$ F. X. FUnK, Didascalia et Constitutiones, I, págs. 408-409). Respecto a la prohibición para los cristianos de celebrar la Pascua en el mismo momento en que lo hacían los judíos y según sus costumbres, vid. Const. Apost., VIII, 47, 7 (M. Metzger, Les Constitutions, III, pág. $276=$ F. X. Funk, Didascalia et Constitutiones, I, págs. 566-567).

${ }^{169}$ Maximino, Contr. Iud., V, 1 (CCL 87, pág. 100 = IV, 17-18: C. H. TURNER, «St. Maximus of Turin Contra Iudaeos», pág. 298). Cfr. I homilía anónima, 7 (J. LIÉBAERT, Deux homélies anoméennes, pág. 66); Op. Imp., cols. 614-615. 
salutaris cordis est) ${ }^{170}$. El obispo arriano aseguraba también que si la salvación se lograba únicamente por medio de este signo carnal, las mujeres estarían privadas de toda esperanza salvífica; en cambio, el verdadero signo cristiano de la cruz, marcado en la frente con la sangre de Cristo, salvaba a los creyentes de ambos sexos ${ }^{171}$. Para él, lo que verdaderamente circuncidaban los judíos era la dulce fragancia de Abrahán y no el mal olor de su infidelidad, razón por la que nunca alcanzarían la anhelada salvación:

[...] ¡Ojalá tuvieseis la circuncisión del corazón y no la deshonesta del cuerpo! ¡Ojalá tuvieseis el olor de la fe de Abrahán y no la pestilencia de vuestra perfidia! Sois más bien hijos de las serpientes que, al llevar en vosotros mismos el veneno (pues provocáis la muerte a vuestros padres y por ello mismo asesináis a los demás), preparáis vuestra propia destrucción $[\ldots]^{172}$.

${ }^{170}$ Maximino, Contr. Iud., VI, 1-3 (CCL 87, pág. 102 = IV, 42-65: C. H. TURNER, «St. Maximus of Turin Contra Iudaeos», pág. 299). Vid. A. LuKYN WiLliams, Adversus Judaeos, págs. 308-309; M. MESLIN, Les ariens, pág. 370; H. SCHRECKENBERG, Die christlichen Adversus-Judaeos-Texte, pág. 332.

${ }^{171}$ Maximino, Contr. Iud., VIII, 1 (CCL 87, pág. 105 = VI, 1-6: C. H. TURNER, «St. Maximus of Turin Contra Iudaeos», pág. 301): [...] Si circumcisionem dicitis signum esse salutis, ergo femine aput uso non habent signum salutis. Aput nos autem in signo domini omnes pariter maculi feminaeque signantur; in signo domini signamur in fronte super duos postes de sanguine agni dei, qui tollit peccata mundi [...]. Vid. A. LuKYN Williams, Adversus Judaeos, pág. 307; B. BLumENKRANZ, Les auteurs, pág. 19; M. MESLIN, Les ariens, pág. 370; R. KAMPLING, Das Blut Christi und die Juden, pág. 114; H. SChreCKEnBerg, Die christlichen Adversus-Judaeos-Texte, pág. 332.

${ }^{172}$ Maximino, Contr. Iud., V, 1 (CCL 87, pág. 100 = IV, 17-21: C. H. TuRner, «St. Maximus of Turin Contra Iudaeos», pág. 298): [...] Vtinam haberitis circumcisionem cordis et non dehonestationem corporis! Vtinam haberetis odorem fide Abrahae et non bromositatem perfidiae uestrae! Vos filli estis potius uiperarum in uobis ipsis uenena portantes, qui parentibus infertis necem et ex hoc ipso quo alios occiditis, uobis ipsis interitum preparatis. Tal y como opinaba A. LUKYN Williams (Adversus Judaeos, pág. 308, n. 3), es muy probable que Maximino aludiera en este pasaje al olor de los perfumes que usaban los judíos en sus fiestas y, en concreto, después de la celebración del rito de la circuncisión. La comparación de los judíos con las víboras que, al nacer, desgarran las entrañas de su madre, imagen inspirada en Sal 58 (57), 4-5 y Mt 3, 7, aparece también en $O p$. Imp., cols. 651, 884 y 889. Vid. M. MESLIN, Les ariens, pág. 179. 
La única posibilidad de remisión para el pueblo judío era su conversión al cristianismo. Según Maximino, los cristianos debían hacer todo lo posible (aunque sin utilizar la fuerza ${ }^{173}$ ) para que los judíos fuesen arrancados del error y conducidos a través del atrium ueritatis a la salvación. Con la luz de Cristo podrían acceder a la domus del Señor y alcanzar así la Jerusalén celeste, la noua Hierusalem, id est ecclesia ${ }^{174}$. Sin embargo, apenas escritas estas palabras, el obispo arriano reconoce que cualquier esfuerzo en tal sentido estaría abocado al fracaso, debido a la propia obstinación del pueblo de Israel: «los impíos judíos se oponen a esta persuasión y prefieren antes morir que ser vencidos, diciendo: nosotros adoramos a un solo Dios, como está escrito en los libros de Moisés [Ex 20, 3]» ${ }^{175}$. En realidad, como opina M. Meslin, Maximino nunca creyó posible convencerles, ya que el tono agresivo y los dogmáticos argumentos empleados en su tratado no permiten pensar que albergase la esperanza de dicha conversión. Por el contrario, su obra (como la de los

${ }^{173}$ S. Krauss y W. Horbury (The Jewish-Christian Controversy, pág. 41) observan que esa misma renuncia de Maximino al empleo de la fuerza en la conversión de los judíos, sería defendida ocho siglos después por Ramón Lull (12661315), olvidando que parecidos postulados fueron defendidos igualmente por Gregorio el Magno (finales del siglo VI) y, con ciertas matizaciones, por Isidoro de Sevilla (primera mitad del siglo VII), en cuyos escritos, sin duda más cercanos para él, probablemente encontrara el sabio catalán su inspiración.

${ }^{174}$ Maximino, Contr. Iud., X, 1 (CCL 87, págs. 109-110 = VIII, 1-9: C. H. TURner, «St. Maximus of Turin Contra Iudaeos», págs. 304-305). Cfr. Contr. Iud., VII, 3 (CCL 87, pág. $103=\mathrm{V}, 16-20$ : C. H. TURNER, «St. Maximus of Turin Contra Iudaeos», pág. 300); Op. Imp., col. 896. Vid. A. LuKYN WiLliams, Adversus Judaeos, págs. 306-307 y 311; M. MESLIN, Les ariens, págs. 369 y 378.

175 Maximino, Contr. Iud., X, 2 (CCL 87, pág. 110 = VIII, 17-19: C. H. TURNER, «St. Maximus of Turin Contra Iudaeos», pág. 305): [...] Sed huic persuasioni contendunt impii iudaei maluntque mori quam uinci, dicentes: Nos unum colimus deum, sicut scribtum est in libris Moysi [...]. Vid. A. LUKYN WILliams, Adversus Judaeos, pág. 309; B. BlumENKRANZ, Les auteurs, pág. 19; H. SCHRECKENBERG, Die christlichen Adversus-Judaeos-Texte, pág. 333; R. GonZÁlEZ SALINERO, El antijudaísmo cristiano, pág. 193. El autor del Opus Imperfectum (cols. 673, 788 y 807) replica a los judíos que se enorgullecen de su fiel monoteísmo asegurando que, en realidad, adoraban al becerro de oro y que, al ignorar al Hijo de Dios, se habían convertido en sectarios del Diablo. 
autores ortodoxos) estaba destinada a reforzar la doctrina cristiana mediante una amplia argumentación antijudía ${ }^{176}$.

Como conclusión, no resulta necesario añadir nuevas palabras a las que escribí respecto a este tema en otro lugar: «según las fuentes conservadas, puede afirmarse que Maximino y el arrianismo en general participan de la opinión común de otros cristianos que manifestaron sentimientos antijudíos y, de la misma forma que aquéllos, desarrollan un antijudaísmo de tipo religioso. La literatura arriana refleja los reproches habituales del antijudaísmo cristiano y no practica una exégesis del Antiguo Testamento diferente a la de los autores católicos» ${ }^{177}$.

${ }^{176}$ M. MESLin, Les ariens, pág. 365.

${ }^{177}$ R. GONZÁlez SAlinero, El antijudaísmo cristiano, pág. 77. 


\section{RESUMEN}

Según el autor de este artículo, no existen pruebas objetivas para sostener la teoría del filojudaísmo arriano, teoría que con el tiempo se convirtió en un mito. Ningún emperador o rey de profesión arriana favoreció especialmente al judaísmo. La asociación del arrianismo con la religión judía nació de la polémica antiarriana de los autores católicos de los siglos IV y v. La falsedad del mito se confirma con la constatación de la controversia antijudía en la literatura arriana que ha llegado hasta nosotros.

PALABRAS ClAVE: judíos, arrianos, polémica antijudía, antigüedad tardía.

\section{SUMMARY}

According to the author of this article, there is no objective evidence that supports the theory of the Arian pro-Judaism, a theory that has become a myth in the course of time. Neither the Arian emperor nor the king favoured Judaism. The association of Arianism with the Jewish religion developed out of the anti-Arian polemics of the Catholic authors of the $4^{\text {th }}$ and $5^{\text {th }}$ centuries. The falsehood of this myth is confirmed by the existence of an anti-Jewish controversy reflected in the Arian literature that has been preserved.

KEYwORDS: Jews, Arians, anti-Jewish polemic, Late Antiquity. 